\title{
Relations between basalts and adakitic/felsic intrusive bodies in a soft-substrate environment: The South Ouessant Visean basin in the Variscan belt, Armorican Massif, France
}

\begin{tabular}{|r|l|}
\hline Journal: & Canadian Journal of Earth Sciences \\
\hline Manuscript ID & cjes-2015-0230.R1 \\
\hline Danuscript Type: & Article \\
\hline Complete List of Authors: & $\begin{array}{l}\text { Caroff, M.; UMR N 6538 Domaines Oceaniques } \\
\text { Le Gall, Bernard; UMR N 6538 Domaines Oceaniques } \\
\text { Authemayou, Christine; UMR N 6538 Domaines Oceaniques } \\
\text { Bussien Grosjean, Denise; Musée cantonal de Géologie, Quartier UNIL- } \\
\text { Dorigny, Bâtiment Anthropole } \\
\text { Labry, Cyrill; UMR N 6538 Domaines Oceaniques } \\
\text { Guillong, Marcel; Institute of Geochemistry and Petrology, Department of } \\
\text { Earth Sciences, ETH Zurich, Clausiusstrasse 25 }\end{array}$ \\
\hline Keyword: & Armorican Variscides, Visean basin, adakite, peraluminous granite, peperite \\
\hline \multicolumn{2}{|c}{} \\
\hline
\end{tabular}


1 Relations between basalts and adakitic/felsic intrusive bodies in a soft-

2

3 The South Ouessant Visean basin in the Variscan belt, Armorican

4

5

6

$7 \quad$ Martial Caroff ${ }^{\mathrm{a}, *}$, Bernard Le Gall ${ }^{\mathrm{a}}$, Christine Authemayou ${ }^{\mathrm{a}}$, Denise Bussien

8

9

10

11

12

13

14

15

16

17

18

$19{ }^{1}$ Present address : Musée cantonal de Géologie, Quartier UNIL-Dorigny, Bâtiment

20 Anthropole, 1015 Lausanne, Switzerland.
Massif, France
${ }^{a}$ UMR/CNRS n ${ }^{\circ} 6538$ « Domaines Océaniques », Institut Universitaire Européen de la Mer,

* Corresponding author: caroff@univ-brest.fr

21

https://mc06.manuscriptcentral.com/cjes-pubs 


\section{Abstract}

The metasedimentary and magmatic terranes in the southern part of the Ouessant Island (Western Britany, France) are the offshore prolongation of the Léon Variscan metamorphic domain. They mainly consist of micaschists and subordinate amphibolitic lenses (metapillow lavas and volcaniclastic successions) cut by a swarm of trondhjemite sills, together with a large porphyritic monzogranite body, newly dated at $336 \mathrm{Ma}$, and later syenoleucogranitic intrusions. A large spectrum of fluidal peperites, including spectacular "fiamme"-bearing breccias, is observable at the contact between metasediments and most of the intrusives. The coexistence of amphibolitized basalts, adakitic trondhjemites, and peraluminous granites in the inferred South Ouessant basin is assigned to a variety of deep subcontemporaneous processes, including asthenospheric partial melting, high-pressure fractionation in lithospheric reservoirs (or partial remelting of deep crystallized mafic intrusions), and continental crust melting. Implications of these new results are discussed in the Visean basinal framework of the Armorican Massif, formed at an early stage of the Variscan orogeny.

\section{Résumé}

Les formations métasédimentaires et magmatiques de la partie sud de l'île d'Ouessant (Bretagne occidentale, France) correspondent au prolongement occidental du domaine métamorphique varisque du Léon. Elles comportent essentiellement des micaschistes - dans lesquels on trouve quelques lentilles d'amphibolites (anciennes laves en coussin et successions volcano-sédimentaires) - traversés par un réseau de sills trondhjémitiques et un important corps de monzogranite porphyrique, nouvellement daté à $336 \mathrm{Ma}$, ainsi que par des intrusions syéno-leucogranitiques légèrement plus tardives. Un large spectre de pépérites 
47

48

fluidales, comprenant de spectaculaires brèches à « fiammes », peut être observé au contact entre les métasédiments et la plupart des roches intrusives. La coexistence de basaltes amphibolitisés, de trondhjémites adakitiques et de granites peralumineux dans les métasédiments d'Ouessant sud est attribuée à plusieurs processus profonds subcontemporains, incluant : une fusion partielle asthénosphérique, un fractionnement haute pression dans des réservoirs lithosphériques (ou une refusion partielle d'intrusions mafiques profondes) et une fusion de la croûte continentale. Ces nouveaux résultats sont discutés dans le cadre des bassins viséens armoricains, formés à un stade précoce de l’orogenèse hercynienne. Mots clés: Chaîne varisque armoricaine, bassin viséen, adakite, granite peralumineux, pépérite

\section{Introduction}

(1)

Recent studies have shown that peperites are very widespread in volcano-sedimentary basins, regardless of the tectonic context, as for instance: outer shelf-slope basin (Coira and Pérez 2002), back-arc rift (Dadd and Van Wagoner 2002), continental half-graben (Galerne et al. 2006), and semi-arid lake in fault-bounded basin (Erkül et al. 2006). They include a large variety of clast morphologies from blocky to fluidal (globular, ameboidal and pillow-like varieties), as a result of sediment fluidization at the contact with the magmatic bodies (Skilling et al. 2002).

$$
\text { Bimodal magmatism usually occurs in fault-bounded pull-apart continental }
$$
sedimentary basins, as mafic and silicic (or intermediate) magmas ascending through the boundary faults, before intruding or spreading out more or less simultaneously in the sedimentary infill (e.g., Caroff et al. 1996; Schaltegger et al. 1996). Associated basalts are generally anorogenic and display either a tholeiitic (e.g., Schaltegger et al. 1996) or a slightly alkaline affinity (e.g., Saadat et al. 2010). 
82

Such a magmatic environment is documented in the low-grade metamorphic (metasedimentary) terranes of the Ouessant Island, western offshore continuation of the Léon Domain, Armorican Massif (Fig. 1). Emphasis is put here on the analysis and interpretation of still preserved fluidal peperite textures, including uncommon fiamme-bearing granitic breccias. In addition, various magmatic types, with affinities usually reputed inconsistent, such as anorogenic basalts, adakitic trondhjemites and peraluminous granites, are assumed to have emplaced subconcomitantly in the South Ouessant basin, Visean in age.

\section{Analytical techniques}

\section{1. $\mathrm{U} / \mathrm{Pb}$ zircon dating}

(1)

Zircon grains extracted from a monzogranitic sample by standard mineral separation were placed in epoxy resin, polished (equatorial plane), and then imaged by cathodoluminescence (CL; CamScan MV2300, Earth Sciences Institute, University of Lausanne, Switzerland). Avoiding perturbed zones and inherited cores, dating was performed by laser ablation inductively coupled plasma mass spectrometer (LA-ICP-MS ; Resonetics Resolution 155 excimer laser ArF 193 nm and Thermo Element XR magnetic sector; Institute of Geochemistry and Petrology, ETHZ), with the same analytical parameters as in Caroff et al. (2015).

$$
\text { A typical analytical sequence starts with the internal standard analyses (GJ-1), a }
$$
maximum of 24 unknown grains, three natural zircons (Temora, Plesovice and 91500) as secondary standards, and ends with GJ-1. The Glitter software package (van Achtenberg et al. 2001) and Isoplot/Ex v. 4.15 (Ludwig 2008) were used to process and plot the data. Based on Concordia and Tera-Wasserburg diagrams, the analytical validity of each measurement was 
98

99

100

101

102

103

104

105

106

107

108

109

110

111

112

113

114

115

116

117 118 Caroff et al. (2015).

119

120

121

estimated and the intercept age obtained, respectively. Repeated measurements on the GJ-1 show an age of $604.5 \pm 2.0 \mathrm{Ma}(2$ sigma, $\mathrm{n}=17)$ and the Plesovice resultant age is $338.4 \pm 2.2$ Ma (2 sigma, $\mathrm{n}=5$; certified value of $337.13 \pm 0.37$ Ma by Sláma et al. 2008).

\subsection{Whole-rock analyses}

Whole-rock major and trace elements and isotopic ratios were determined at the PSO/IUEM (Pôle Spectrométrie Océan, Institut Universitaire Européen de la Mer, Brest, France). Major elements were analyzed by inductively coupled plasma-atomic emission spectrometry (ICP-AES) using a Horiba Jobin Yvon ${ }^{\circledR}$ Ultima 2 spectrometer and following the analytical procedure of Cotten et al. (1995). Relative standard deviations are $<2 \%(<1 \%$ for $\left.\mathrm{SiO}_{2}\right)$, except for low values $(<0.50 \mathrm{wt} \%)$, for which the absolute standard deviation is \pm $0.01 \mathrm{wt} \%$. Trace elements were determined by high-resolution ICP-MS, using a Thermo Element 2 spectrometer, following the sample preparation and analytical procedure described by Barrat et al. (1996). Relative standard deviations are $<5 \%$ for most of trace elements and $<$ $10 \%$ for $\mathrm{Nb}, \mathrm{Gd}, \mathrm{Tb}, \mathrm{Ta}, \mathrm{Ni}, \mathrm{Zn}$ and $\mathrm{Rb}$. Sr isotopic ratios were measured by thermal ionization mass spectrometry (TIMS), while $\mathrm{Nd}$ isotopic ratios were quantified using a multicollector ICP-MS (PSO/IFREMER, Brest, France). The protocol for element separation is described in White and Patchett (1984).

More details on analytical techniques and complementary references can be found in

\section{Geological setting and age framework}


The Variscan belt of Brittany (western France) consists of a mosaic of structural

domains that have been amalgamated during Carboniferous times along a network of crustal-

scale EW-trending ductile dextral fault zones, e.g. the North and South Armorican Shear

Zones (NASZ and SASZ, Fig. 1a) (Gapais and Le Corre 1980). The Central Armorican

Domain (CAD) is composed of a thick pile of gently folded and schistosed sedimentary rocks,

ranging in age from Proterozoic up to Lower Carboniferous in the Châteaulin and Laval

basins (Fig. 1a) (Le Hérissé and Plaine 1982; Rolet et al. 1986; Darboux and Le Gall 1988;

Gumiaux et al. 2004). The composite block extending north of the NASZ mainly comprises

Cadomian metamorphic and magmatic terranes that mostly escaped Variscan strain, excepted to the west in the highly strained Léon metamorphic domain. This area is separated from the CAD sedimentary rocks to the south by the NASZ system (Fig. 1a, b). To the east, the Léon metamorphic terranes are overlain by sedimentary rocks of the Morlaix Visean basin (Fig. 1a) (Cabanis 1986).

The Léon domain is composed of a northerly-directed thrust stack of metamorphic units emplaced in the time range 440-340 Ma (Paquette et al. 1987). They were later exhumed during a long-lasted transtensional tectonic event, synchronously to granitic processes at 340$300 \mathrm{Ma}$ (Schulz et al. 2007; Marcoux et al. 2009; Le Gall et al. 2014). Two successive ductile shearing episodes, with opposite senses of movement, took place in this time range. Early dextral shearing occurred along the E-W-trending NASZ, synchronously to the intrusion of the Saint-Renan granite at $316 \pm 2 \mathrm{Ma}$ (Le Gall et al. 2014). The emplacement of the younger and sinistral $\mathrm{N} 70^{\circ} \mathrm{E}-$ oriented Plouguerneau-Guisseny ductile shear zone (PGSZ) further north was accompanied by the c. 300 Ma-old Aber-Ildut granitic complex (Caroff et al. 2015).

The Ouessant Island extends offshore of the Léon metamorphic domain (Fig. 1a, b). Its overall $\mathrm{N} 70^{\circ}$-trending structural arrangement involves two distinct areas that differ in terms of both lithological contents and tectonic histories, but that share a common 
147 metamorphic evolution with a HT peak at c. $305 \mathrm{Ma}$ (monazite age from Schulz 2013). The

148 northern area involves various c. 300 Ma-old granitic intrusions (Caroff et al. 2015). There,

149 ductile strain is mainly expressed by the North-Ouessant sinistral shear zone (NOSZ) that

150 forms the offset western offshore prolongation of the above-mentioned PGSZ. The Central-

151 Ouessant shear zone (COSZ) separates the North Ouessant area from the metasedimentary

152 and magmatic rocks of the 2-3 km-wide South Ouessant area, under study here (Fig. 1b and

153 2). There, highly strained micaschists are intensely intruded by a swarm of

154 (micro)trondhjemite sills and by a K-feldspar porphyritic granitoid, extending as either a map-

155 scale intrusion or thin sills. Slightly younger muscovite granitoid intrusions locally occur in

156 contact with either porphyritic granitoid or micaschists. The latter also contain, to the south,

157 subordinate amphibolitic layers and lenses (Fig. 2). The South Ouessant

158 metasedimentary/metavolcanic formations recorded an amphibolite-grade metamorphism

159 (Schulz 2013) that increased slightly southwards.

160 The porphyritic monzogranite 14DB01 yields a Concordia age of $336.3 \pm 2.3 \mathrm{Ma}(1$

161 sigma, MSWD = 1.4), slightly older than its ${ }^{206} \mathrm{~Pb} /{ }^{238} \mathrm{U}$ age of $335.7 \pm 2.4 \mathrm{Ma}(1$ sigma,

$162 \mathrm{MSWD}=1.3$ ) (Fig. 3 and Table S1). From field relationships (see section 4.2.), it is further

163 argued that this magmatic event, which predated regional strain and metamorphism in the

164 South Ouessant area, occurred synchronously to initiation of the so-called South Ouessant

165 basin (SOB in the text). As assuming the Visean age of the SOB, our results supply quite new

166 insights about the early Variscan basinal/magmatic history experienced by Lower

167 Carboniferous terranes, west of the Leon metamorphic domain. The SOB is assumed to be

168 part of the network of intra-continental sedimentary basins documented further east in the

169 CAD (Châteaulin, Morlaix and Laval), and also in the South Armorican Domain (Ancenis)

$170 \quad$ (Fig. 1a).

171 
172

173

174

175

176

177

178

180

181

182

183

184

185

186

187

188

189

190

191

192

193

194

195

196

\section{Field relationships}

\subsection{Pillow lavas and volcaniclastic successions}

Metavolcanic formations crop out punctually in the form of amphibolitic intercalations in micaschists along the southern coast of the South Ouessant Island (Chauris 1994) (Fig. 2). Two early types are exposed, as lavas and volcaniclastic successions.

Despite intense strain and metamorphism (Schulz 2013), ancient effusives still show recognizable initial pillow-like structures in the Porz Doun sector (Fig. 2), in contact with micaschists. Most of them display an ovoid form (Fig. 4a), sometime stretched by tectonics, and some are bordered by a chilled margin (Fig. 4b, c). They are massive, showing no internal structures.

Ancient volcaniclastic successions are more common than the pillow lavas. They comprise alternations of light (quartz-dominant) and dark (amphibole-dominant) thin-layered (from a few millimeters to a few centimeters in thickness) clast-bearing volcanic-derived deposits (Fig. 4d). Either light or dark layers may be prevalent. The beds, generally regular, are sometimes of variable thickness, displaying undulated and beveled forms. Although their volcanic origin is not in doubt, the scarcity of original deposit features, together with significant metamorphic recrystallizations, make the interpretation of initial breccias very difficult. Nevertheless, it is here assessed that the layer thickness pattern, as well as the local presence of lenticular and corrugated (amphibole-bearing) thin beds (Fig. 4e), typically resemble the bedded eruption-fed submarine facies described elsewhere by McPhie and Allen (1992), Caroff et al. (2009), and Jutzeler et al. (2014).

\subsection{Silicic intrusions}


Trondhjemites and microtrondhjemites occur as a dense and folded sill/dyke network

199 in the micaschists, north of the SOB (Fig. 2). The greatest body can be observed to the east, in 200 the Stiff Bay. It is an ENE-WSW-trending $200 \mathrm{~m}$-thick sill, more than $1 \mathrm{~km}$ in length, cut by 201 a subvertical network of NS-trending normal faults (Chauris 1994). The other occurrences, in 202 the Stiff Bay and, to the west, in the Lampaul Bay, are up to 10's m-thick intrusions. Contacts 203 between (micro)trondhjemites and micaschists systematically display finger-shaped, rounded 204 or lobate morphologies (Fig. 4f).

205 The main magmatic formation in South Ouessant is a schistosed K-feldspar 206 porphyritic granitoid that forms either a map-scale intrusion in the micaschist host-rocks to 207 the east or a dense sill/dyke swarm, of variable thickness, to the west (Fig. 2). Special 208 attention has been paid to the remarkable porphyritic granitoid/metasediment contacts. That 209 provides quite original new insights about the conditions of emplacement of the porphyritic 210 intrusives in the SOB infill. In some places, the silicic intrusions form undulated sills, 211 insulated amoeboid bodies (Fig. 4g), or even frozen descending crystal-bearing plumes (Fig. 212 5a) in the metasediment. Elsewhere, contacts are more diffuse and metasediment appears to 213 be loaded with isolated feldspar crystals, whilst magmatic intrusions only occur as small-sized 214 undulated lodes or veinlets (Fig. 5b). Such features undoubtedly show analogies with 215 magma/sediment mingling facies (peperites) described elsewhere (e.g., Skilling et al. 2002;

216 Martin and Németh 2007). Additional interaction facies corresponds to fiamme-bearing 217 breccias (see 4.3).

218 A third type of felsic intrusions is evidenced in the SOB metasedimentary infill. It 219 consists of a largely-distributed sill/dyke network of a schistosed muscovite granitoid. The 220 main intrusion has a thickness of c. $100 \mathrm{~m}$. To the south-west, sills and dykes cut through the 221 micaschists, the porphyritic granitoid and/or the mingling facies (Fig. 2). From these mutual 
222

223

224

225

226

227

228

229

230

231

232

233

234

235

236

237

238

239

240

241

242

cross-cutting relationships, further completed by the observation of undulate, finger-shaped

(Fig. 4h) and lobate contacts between the muscovite-bearing granitoid and metasediment (less marked than about the porphyritic granitoid), it is firmly assumed that the intrusion of the muscovite granitoid predated the complete lithification of the sediment and postdated the emplacement of the porphyritic granitoid.

\subsection{Fiamme-bearing peperitic breccias}

Remarkable interaction facies between porphyritic granitoid and micaschist can be observed in a small embayment of the coastline south of the south-western headland (Porz an Ejen, Fig. 2). There, elongate metasedimentary clasts are embedded within a mingled matrix where granitoid and micaschist materials are hardly distinguishable, hence forming fiammebearing schistosed breccias (Fig. 5c and d). Some metasedimentary "flame-like" lenses extend parallel to the regional schistosity, others not. Consequently, tectonics does not seem to be at the origin of the clast elongation, even if it could have locally contributed to it. The lenseshaped metasedimentary clasts of the SOB mingled breccias are confidently regarded as fiammes, i.e. elongate lenses or domains of similar mineralogy, texture and composition within a contrasted material, hence resulting in an early (pre-tectonic) foliation-like structure (following the definition of Bull and McPhie 2007).

Approximately $500 \mathrm{~m}$ east of the previous sector, a mingling facies between porphyritic granitoid and metasediments encloses lenses of graphite-bearing micaschists, similar to the abovementioned fiammes but not oriented, in the process of detaching from the main metasedimentary bodies (Fig. 6). Such specific magma-sediment features might be regarded as highly evolved peperitic facies (Skilling et al. 2002; Caroff et al. 2009), in turn arguing for the syn- (or slightly post-) depositional emplacement of the porphyritic granitoid 
247 intrusions. As the other magmatic units of the SOB also display peperitic contacts, all of them

248 can thus be considered as subcontemporaneous at c. $336 \mathrm{Ma}$.

\section{Textural and petrological notes}

\subsection{Sampling and nomenclature}

Most samples were collected in 2014 and 2015 along the southern coast of the

Ouessant Island. In addition, new data on lavas from the northern edge of the Châteaulin basin

and the southern part of the Laval basin, respectively sampled in 1994 and 1999, are also presented here (Table 1).

The petrographic nomenclature of lavas and (pre-metamorphic) amphibolites is based on the total alkali-silica (TAS) classification scheme of Le Maitre et al. (2002) (not shown).

The granitoid nomenclature is based on the Q' vs. ANOR diagram (not shown), derived empirically by Streckeisen and Le Maitre (1979) from the IUGS classification of Streckeisen (1976) and considered as its CIPW normative equivalent. The samples OS10 and OSB30, which plot in the right part of the granodiorite field of the Q' vs. ANOR diagram, display a mineralogy of (micro)trondhjemite (see below) and, thus, will be considered as such.

\subsection{Micaschists}

Texture and mineralogy of the SOB micaschists change progressively from north-west

269 to south-east in the area. In the central part of the island, micaschists are glossy and mainly made up of muscovite, chlorite and quartz. Great chloritized biotite crystals are sparsely 
272 almandine, 1-2 mm-long staurolite, sparse andalusite, and euhedral tourmaline (Chauris

273 1994). Quartzite beds are observable in several places in the glossy micaschists. Along the

274 southern coast, micaschists are distinguished by the presence of numerous great poikiloblastic

275 muscovite crystals, secant with respect to schistosity. Other minerals are, in order of

276 decreasing abundance: biotite, quartz, garnet - red almandine and yellow grossular - with

277 lengths ranging from $3 \mathrm{~mm}$ to $4 \mathrm{~cm}$ (Chauris 1994), late poikiloblastic tourmaline, and

278 plagioclase. Graphite is locally present in significant quantities, as shapeless patches in the

279 poikiloblastic micaschist or as clasts in the granitoid/micaschist fiamme-bearing mingled

280 breccias (Fig. 5c). An intermediate facies between glossy and poikiloblastic micaschists

281 occurs along the north-west coast of the south-western headland.

282

283

5.3. Amphibolites

284

The highly stretched amphibolitized pillow lavas, basaltic in composition, have a nematoblastic texture. They contain aligned green hornblende, quartz, sericitized plagioclase,

287 ilmenite, apatite and subordinate titanite (Fig. 7a). A few retromorphozed pillow lavas typically contain greenschist facies assemblage of actinolite, chlorite and epidote, in addition to altered plagioclase, quartz, ilmenite and apatite.

The volcaniclastic layered breccias are characterized by a succession of beds

alternately light and dark. The light layers are mainly formed of quartz and plagioclase (either

292 one of these two minerals is the most abundant), then also green hornblende, Fe-Ti oxides and

293 apatite. Texture is either clastic or granoblastic. The dark layers contain mainly green

294 hornblende with a nematoblastic texture. Subordinate minerals are quartz, plagioclase, biotite,

295 muscovite, Fe-Ti oxides, and apatite. Light layers are sometimes disturbed by the presence of

296 millimeter-sized nematoblastic amphibolitized clasts. A hornblende-dominant bedded breccia 
297 from Porz Doun (Fig. 2) contains a remarkable clast, several centimeters in size, which still

298 shows a preserved primary texture and mineralogy. It is mainly constituted of augite and

299 plagioclase, making layers that range from macro- to microgranular textures.

300

301

5.4. Trondhjemites and microtrondhjemites

302

303

304

instead shows a porphyritic coarse-grained texture. In both cases, phenocrysts are euhedral

306

square-section Na-rich plagioclase crystals, up to $7 \mathrm{~mm}$-long (Fig. 7b). Their twins often

307

display mechanical distorsions. Groundmass minerals are quartz with undulose extinction,

rare chloritized biotite and late muscovite.

309

Sample OSB30 has been taken from a 5-10 m-thick microtrondhjemitic intrusion

310 located west of the island, whereas sample OS10 is from the $200 \mathrm{~m}$-thick trondhjemitic sill in

311 the Stiff Bay (Fig. 2).

312

313

5.5. Granites

314

315

The porphyritic granitoid is a monzogranite following the classification scheme of

316 Streckeisen and Le Maitre (1979). Its porphyritic texture is supported by 1-2 cm-long square-

317 section feldspar crystals (microcline or orthoclase, and oligoclase) (Figs. 4g and 5b), with

318 local myrmekite structures (Fig. 7c). Quartz is also present as large crystals with undulose

319 extinction and small contiguous recrystallized crystals, as well as biotite, apatite, and late

320

tourmaline. Muscovite is lacking or very rare. In the Porz an Ejen mingled complex (Fig. 2), 
321 intense fragmentation of the monzogranite results in K-feldspar megacrysts embedded within

322 the graphite-bearing poikiloblastic micaschist host rock (Fig. 8a).

323 Following the Q' vs. ANOR diagram of Streckeisen and Le Maitre (1979), the

324 muscovite granitoid divides into two contemporaneous petrographic types, both with a

325 granular texture, i.e. syenogranite and K-feldspar leucogranite. The first one is made up of K-

326 feldspar, quartz, plagioclase, muscovite, biotite, and apatite. In the second type, very light

327 colored, the mica population is dominated by muscovite (Fig. 7d). Leucogranitic intrusions

328 often contain disseminated tourmaline and garnet. Pegmatite occurrences are frequently

329 associated with them. An example of microtexture of the lobed contacts between coarse-

330 grained tourmaline-bearing leucogranite and fine-grained metasediment is shown in Fig. 8 b.

331 There is no clear limit between both lithologies, but a 2-4 mm-large biotite-rich transition

332 zone.

\section{6. Geochemistry}

\subsection{Major elements}

Glossy and poikiloblastic micaschists, occurring respectively north and south of the

339 SOB, display contrasted major element compositions. The glossy micaschist LC1 is more

340 siliceous and more aluminous than the poikiloblastic micaschist LC5, which is, by contrast,

341 enriched in $\mathrm{CaO}$ and $\mathrm{K}_{2} \mathrm{O}$. The local presence of grossular in the latter type may be related to

342 relatively high $\mathrm{CaO}$ contents.

343 The South Ouessant amphibolites plot in the basalt field in the TAS diagram of Le

344 Maitre et al. (2002). They are characterized by high content in $\mathrm{TiO}_{2}(>1.8 \mathrm{wt} \%$, Table 1 and

345 Fig. 9a) and by $\mathrm{P}_{2} \mathrm{O}_{5}$ values ranging from 0.2 to $0.4 \mathrm{wt} \%$ (Table 1 and Fig. 9b). Their major 
346 element composition is compared in Fig. 9 with that of mafic lavas from contemporaneous

347 basins in the CAD and of Visean dolerites from Saint-Malo (North Armorican Domain). The

348 highest $\mathrm{TiO}_{2}$ values concern the mafic rocks from Laval, Châteaulin and Saint-Malo, whereas

349 the lowest $\mathrm{TiO}_{2}$ contents correspond to the Morlaix and South Ouessant amphibolites (Fig.

350 9a). $\mathrm{P}_{2} \mathrm{O}_{5}$ is especially high in the Laval basalts $(>0.6 \mathrm{wt} \%)$ and low in the Morlaix

351 amphibolites $(<0.3 \mathrm{wt} \%)$; the other mafic rocks plot between these values (Fig. 9b). The

352 andesite sample KR22 from the Châteaulin basin shifts to the right in both diagrams $\left(\mathrm{SiO}_{2}=\right.$

$35361.80 \mathrm{wt} \%$, Table 1). All the Visean mafic rocks from the Central and North Armorican

354 Domains plot at the intersection between the Ocean Island, Ocean Ridge and Continental

355 basalts fields in the triangular discrimination diagram of Pearce et al. (1977) (Fig. 9c).

356 Accordingly, all of them have a clear anorogenic affinity.

357 The SOB felsic rocks are characterized by high $\mathrm{SiO}_{2}$ contents $(>67 \mathrm{wt} \%$, Table 1 and

358 Fig. 9a, b). The syenogranite $\mathrm{OS} 3 \mathrm{c}$ has a $\mathrm{K}_{2} \mathrm{O} / \mathrm{Na}_{2} \mathrm{O}$ ratio higher than that of the

359 monzogranites (1.57 vs. 0.96-1.02, Fig. 9d). All the granites from the SOB are peraluminous,

360 i.e. with ratios of molecular $\mathrm{Al}_{2} \mathrm{O}_{3} /\left(\mathrm{CaO}+\mathrm{Na}_{2} \mathrm{O}+\mathrm{K}_{2} \mathrm{O}\right)$ or ' $\mathrm{A} / \mathrm{CNK}$ ' exceeding 1: 1.07-1.13 for

361 the porphyritic monzogranites, 1.16 for the syenogranite OS3c, and $>1.15$ for the tourmaline-

362 bearing leucogranite LC29. Syeno- and leucogranites from South Ouessant can even be

363 considered as strongly peraluminous rocks, following the criterion of Sylvester (1998):

$364 \mathrm{~A} / \mathrm{CNK} \geq 1.1$. In the $\mathrm{K}_{2} \mathrm{O} / \mathrm{Na}_{2} \mathrm{O}$ vs. $\mathrm{SiO}_{2}$ diagram of Fig. 9d, the South Ouessant

365 (micro)trondhjemites plot within the of the high-silica adakite (HSA) field, close to the

366 trondhjemites from the Morlaix Visean basin (Fig. 9d).

367

368

6.2. Trace elements

369 
The South Ouessant and Morlaix amphibolites are characterized by low La/Eu and $\mathrm{La} / \mathrm{Tb}$ ratios (Fig. 10a). The Laval basalts have the highest $\mathrm{La} / \mathrm{Eu}$ and $\mathrm{La} / \mathrm{Tb}$ ratios, while mafic rocks from Châteaulin and Saint-Malo areas plot between them. These features are also evidenced in the chondrite-normalized rare earth element diagram of Fig. 11a. As such, all mafic rock patterns display a negative slope from middle to heavy rare earth elements (MREE and HREE), with the steepest negative slope about the Laval basalts. The SOB and Morlaix amphibolites again show a specific signature, with their light rare earth elements (LREE) concave-down shaped patterns (Fig. 11a). In the discrimination diagram of Cabanis and Lecolle (1989) (Fig. 10b), all the Visean mafic rocks from the Central and North Armorican Domains show an anorogenic affinity, as plotting close to the E-MORB field for South Ouessant and Châteaulin, in the alkali basalt field for Laval, and in the intracontinental tholeiite field for Saint-Malo (Morlaix not plotted).

The SOB (micro)trondhjemites plot clearly within the HSA fields of Fig. 10c and d. Their REE patterns, although grossly parallel to those of the granites, are quite distinct as being lower and devoid of Eu negative anomaly (Fig. 11b).

\subsection{Isotopes}

The new Sr and Nd isotopic ratios from the SOB and North Châteaulin basin are presented in Table 2 (only the Sr ratio is available for the syenogranite OS3c) and reported in the $\varepsilon_{\text {Nd }}^{\mathrm{t}}$ vs. initial ${ }^{87} \mathrm{Sr} /{ }^{86} \mathrm{Sr}(\mathrm{t}=336 \mathrm{Ma})$ diagram of Fig. 12. The ${ }^{87} \mathrm{Sr} /{ }^{86} \mathrm{Sr}_{\mathrm{i}}$ value of the microtrondhjemite OSB30 is obviously aberrant (0.73417, Table 2), possibly because of alteration processes, and as such is not plotted in the Fig. 12 diagram. The field of the c. 300 Ma Aber-Ildut/North-Ouessant (AI-NO) complex is also indicated, for comparison. 
The monzogranite 14DB01 and the syenogranite OS3c have isotopic compositions

395 comparable to those of the equivalent lithologies in the AI-NO complex (Caroff et al. 2015). Microtrondhjemites are characterized by lower initial ${ }^{87} \mathrm{Sr} /{ }^{86} \mathrm{Sr}$ ratio and positive - or slightly negative - initial $\varepsilon_{\mathrm{Nd}}\left({ }^{87} \mathrm{Sr} /{ }^{86} \mathrm{Sr}_{\mathrm{i}}[\mathrm{OS} 10]=0.70426 ;-0.5<\varepsilon^{336}{ }_{\mathrm{Nd}}<2.2\right)$. The initial $\varepsilon_{\mathrm{Nd}}$ of the amphibolite OS8 (3.0) is close to those of the microtrondhjemite OSB30 / North Châteaulin andesite KR22 ( $\varepsilon^{336}{ }_{\mathrm{Nd}}=2.2$ in both cases). The North Châteaulin basalt KR3 shows a very

high $\varepsilon^{336}$ Nd value of 5.9. The relatively high ${ }^{87} \mathrm{Sr}^{86} \mathrm{Sr}_{\mathrm{i}}$ of sample OS8 with respect to KR3 and KR22 (Table 2 and Fig. 12) might result either from an early seawater alteration process (pillow lava stage) or fluid circulations during metamorphism.

\section{Discussion}

\subsection{Visean fault-bounded basins in the Léon and Central Armorican Domains}

sedimentary infill and syndepositional magmatism. Indeed, their respective basal deposits, Tournaisian-Visean in age, are dominated by terrigeneous sequences, coeval to a mafic/silicic (or intermediate) effusive volcanism (Le Hérissé and Plaine 1982; Cabanis 1986; Le Gall 1992; Caroff et al. 1996; Ducassou et al. 2014). Since these initial sedimentary and magmatic features consistently occur along the margins of the developing basins, they can be assigned to boundary fault-induced processes. The inferred early fault networks are also usually thought to have controlled the emplacement of the Châteaulin and Laval basins as pull-apart structures (Rolet 1984). With respect to this long-lived and EW-trending crustal-scale fault pattern, the submeridian Morlaix Carboniferous basin occupies a specific location, as separating the Léon metamorphic domain (west) from the North Armorican Cadomian block 
419 (east), north of the NASZ (Fig. 1a). Its emplacement might have been controlled by a

420 submeridian zone of crustal weakness that expresses at the surface by the restricted map-scale

421 distribution of a trondhjemite dyke swarm, Carboniferous in age (Chauris 1992).

422 The SOB currently lies as a narrow structure (2-3 km wide) bounded by two EW-

423 trending ductile shear zones (Fig. 1b) that thus prevent any precise restoration of its initial

424 geometry and dimensions. Given the age yielded by the monzogranite 14DB01 and the

425 geochemical resemblances displayed by the basaltic(/amphibolitic) compositions in the entire

426 Visean basin network (Figs. 9, 10, 11, and 12), the SOB is here assumed to be the

427 westernmost fault-bounded intracontinental basins in the Armorican belt, possibly initiated in

428 a transtensional regime (Fig. 13). The chemical differences between glossy and poikiloblastic

429 micaschists within the SOB (Table 1) likely reflect either contrasted lithological content in the

430 sedimentary infill (Fig. 13) and/or hydrothermal effect linked to magmatism along the

431 inferred southern basin boundary.

432 A restored basinal template of the CAD between c. 340 and $330 \mathrm{Ma}$ is attempted in

433 Fig. 14. The corresponding sedimentary depocenters are known to have been partly controlled

434 by $\mathrm{N} 70^{\circ} \mathrm{E}$-trending extensional boundary faults, subsequently reactivated as dextral ductile

435 shear zones during the Variscan shortening (green arrows in Fig. 14). The Saint-Malo

436 doleritic dyke swarm corresponds to contemporaneous intrusions, with geochemical features

437 very close to those of the North Châteaulin basalts (Figs. 9, 10, and 11; see also Caroff et al.

438 1996). According to this restored Visean basinal framework, the South Ouessant and Morlaix

439 basins occupied comparable structural positions, at the western and eastern edges of the Leon

440 Domain, respectively. That basinal setting matches with the very close chemical composition

441 of their respective amphibolites, especially in REE elements (Figs. 10a and 11), and also with

442 the presence of trondhjemite intrusions in both basins (Fig. 9d). 
444

445

446

447

448

449

450

451

452

453

454

455

456

457

458

459

460

461

462

463

464

465

466

467

468

\subsection{Formation of peperites}

"Peperite" is a generic term applied to the rocks formed in situ by disintegration and/or mingling of magma (lava or intrusion) at the contact with unconsolidated or poorly consolidated, typically wet sediments (White et al. 2000). Magma fragmentation produces

two types of peperites, which are called fluidal and blocky, in reference to the dominant shape of the clasts (Skilling et al. 2002). Clasts in fluidal peperites have globular or amoeboid morphology, with complex outlines; blocky clasts are polyhedral to tabular, with subplanar surfaces (Skilling et al. 2002). While blocky clasts imply disintegration of magma in the brittle regime, fluidal peperites are, in contrast, fragmented in the ductile regime, with stable vapor films along magma-sediment preventing direct contact with the pore fluid (Skilling et al. 2002).

In the SOB under study here, peperites are predominantly fluidal. A large range of morphologies can be observed from lobed margins in dykes and sills (Fig. 4f, h) to fiammebearing breccias (Fig. 5d) through globular and amoeboid bodies (Fig. 4g).

Microtrondhjemites and leucogranites display only moderately corrugated contacts with the metasedimentary host rocks, whereas monzogranites are locally entirely disintegrated within sediment (Fig. 5a, b, d). These features suggest that the emplacement of the monzogranitic intrusions within the sedimentary material took place at an early stage, prior to the other granitoids, and when the sediment was in a less consolidated state. This is consistent with the field cross-cutting relationships showing that syeno-leucogranites obviously post-date monzogranites (see section 4.2).

Three features are especially remarkable in the South Ouessant peperites: (1) the high degree of monzonite disintegration; (2) the local presence of fiamme-bearing breccias; and (3) the fact that most peperitic magma bodies have a coarse-grained texture, even near magma- 
469 sediment contacts. The first two features are listed in the summary of characteristics of

470 peperite domains by Skilling et al. (2002), as "close-packed peperites" and "oriented sediment

471 grains", respectively. One of the most striking features about the close-packed peperites

472 documented here is that the fragmented monzonite is highly porphyritic, hence resulting in

473 apparent K-feldspar crystals isolated within the metasediment (Fig. 8a). In the east sector of

474 Porz an Ejen (Fig. 6 insets), we can observe detachment of fiammes from coherent

475 sedimentary bodies and incorporation within monzonite. In this sector, the metasediment

476 clasts are elongate but not oriented (Fig. 6), contrary to little further west (Fig. 5c, d). This

477 implies that the monzonitic magma intruded very soft sediment, flaked off and incorporated

478 elongate sedimentary fiamme-shaped fragments and, sometimes, moved forward, which

479 oriented them. The striking coarse-grained texture of monzonite and syeno-leucogranite near

480 the contacts with metasediment (Fig. 8b) has, to our knowledge, never been so far described

481 in peperitic context. One should have rather expected to observe quenched or microgranular

482 textures. Such an unexpected feature may result from (i) influx of fluid in the early stage of

483 emplacement, which can have in turn affected the textural coarsening by maintaining a low

484 degree of undercooling in magma (Yang 2012), (ii) subsequent formation of sustainable

485 insulating vapor films at the magma-sediment contacts, which can have inhibited fluid loss,

486 explosion and/or quenching, and (iii) metamorphic recrystallizations. Biotite-rich transition

487 zones at the leucogranite/metasediment contacts (Fig. 8b) may have been the consequence of

488 these processes.

489

490 7.3. Contemporaneous mantle- and crust-derived magmas

491

492 The positive $\varepsilon^{336}$ Nd value of the amphibolitized basalt OS8 shows that it is undoubtedly

493 a mantle-derived product. By contrast, the $\mathrm{Sr}-\mathrm{Nd}$ isotopic compositions of the SOB 
494 peraluminous granites fit with those of the AI-NO granitoids, which have been recently

495 interpreted by Caroff et al. (2015) as entirely - or predominantly - crust-derived materials.

496 Lastly, adakitic trondhjemites display isotopic compositions midway between those two. Field

497 relationships indicate that these three syn- (or slightly post-) depositional magmatic groups

498 are overall contemporaneous. Simultaneous emplacement of magmas having such contrasting

499 affinities in a very narrow area is, at the least, surprising and implies a specific range of

500 genetic processes.

501 Assuming that the SOB was a transtensional basin, as similarly applied to most of

502 Visean basins in the CAD, suggests that its syndepositional basalts probably rose up from

503 deep levels through its border faults, as already discussed by Caroff et al. (1996) for the North

504 Châteaulin basalts. The fact that these latter have major and trace element compositions very

505 close to those of Hawaiian oceanic tholeiites (Caroff et al. 1996) rather suggests an

506 asthenospheric source for them and, more generally, for all the Visean CAD mafic rocks. The

507 increasing alkalic character of the Visean basalts/dolerites/amphibolites from SOB/Morlaix

508 (E-MORB) and Châteaulin/Saint-Malo (transitional basalts) to Laval (alkali basalts) (Figs. 9a,

$509 \mathrm{~b}, 10 \mathrm{a}, \mathrm{b}$, and 11) is consistent with decreasing degrees of partial melting of the mantle source

510 eastwards, concomitantly with an inferred lithospheric thickening (Fig. 14). Peraluminous

511 granitic magmas are reputed to be chiefly crust-derived melts (Frost et al. 2001; Caroff et al.

512 2015). On the other hand, the most likely ways to generate HSA-type adakitic magmas are

513 either (i) by partial melting of metabasalts or metagabbros in the field of garnet stability

514 (Moyen 2009 and references herein) or (ii) by deep fractionation of a garnet-dominated

515 assemblage (Macpherson et al. 2006). The lack of Eu anomaly in the SOB

516 (micro)trondhjemites can be explained in different ways: (1) plagioclase was absent during

517 high pressure melting or crystallization; (2) plagioclase was in competition with phases

518 having positive distribution coefficients for $\mathrm{Sm}$ and $\mathrm{Tb}$ (e.g., amphibole or apatite), leading, 
519 by compensation, to no Eu anomaly; or (3) oxygen fugacity was high during melting or 520 crystallization (Shearer and Papike 1989).

521 The origin the SOB magmatic intrusions should be strictly assigned to the following

522 processes (depicted in Fig. 14), given the petrologic and geochemical constraints listed above.

523 (1) Asthenospheric partial melting resulted in basaltic liquids that rose and erupted, or

524 crystallized in deep reservoirs. (2) Partial remelting of deep mafic intrusions resulting from 525 stage (1) - or high-pressure fractionation in deep reservoirs - produced adakitic liquids. Such

526 a lithospheric partial melting could have been caused by asthenospheric advective heating 527 associated with the Léon exhumation event (Schultz 2013; Le Gall et al. 2014; Caroff et al.

528 2015). (3) Heating of the continental crust by mafic injections might have produced silicic

529 melts that rose and emplaced as peraluminous granites. Assuming that the genetic model

530 proposed by Caroff et al. (2015) for the North Ouessant granitic complex can be applied to the

531 SOB granitoids implies that syeno-leucogranites likely originated from pure crustal melting,

532 whereas monzogranitic products would result from mixing between crustal melts and mantle533 derived mafic liquids.

534

535

8. Conclusions

536

1. Though the South Ouessant metasedimentary and magmatic rocks are highly tectonized and metamorphized under amphibolite facies conditions, their age, petrology and

539 geochemistry have been precisely defined, hence leading us to identify an early basin, Visean

540 in age, at the western offshore extremity of the Léon and Central Armorican Domains.

2. Contacts between metasedimentary materials and magmatic bodies display a large

542 spectrum of quite original fluidal peperitic features, from lobed or amoeboid sill/dyke rims to

543 fiamme-bearing polygenic breccias. One of the most noticeable aspects of these unusual 
544 peperites is that they include coarse-grained granites. The South Ouessant composite

545 magmatic complex as a whole is thus assumed to have emplaced at a relatively high crustal

546 level, into not yet indurated and lithified Visean sediments.

547 3. From a magmatic point of view, the South Ouessant basin comprises three types of

548 subcontemporaneous rocks, issued from very different sources, i.e. (1) sparse amphibolitized

549 basaltic pillow lavas and associated volcaniclastic breccias, (2) a sill/dyke swarm of adakitic

550 (micro)trondhjemites, and (3) large intrusions of peraluminous granites. Emplacement of such

551 a contrasted magmatic complex within a very narrow basin and in a brief time period

552 necessarily requires the following subconcomitant mechanisms: (1) asthenospheric partial

553 melting prone to generate basaltic liquids that later rose up through the basin border faults, (2)

554 high-pressure fractionation in deep reservoirs (or partial remelting of deep gabbroic

555 intrusions) leading to adakitic products, and (3) continental crust melting from which

556 originated peraluminous silicic melts.

557

558

559

560

561

562

563

564

565

566

567

568

Supplementary data to this article can be found online at...

\section{Acknowledgements}

Detailed and constructive comments by Dr. Yener Eyuboglu and by two anonymous reviewers helped us to improve the text. The authors are grateful to C. Bollinger (ICP-MS Brest), P. Nonnotte (TI-MS), C. Liorzou (ICP-AES), M.-L. Rouget (chemistry lab assistant, UMS n³113), A. von Quadt (U/Pb geochronology, ETH Zurich), P. Vonlanthen (Scanning electron microscopy, Institut des Sciences de la Terre, Lausanne), G. Chazot

(photomicrographs), P. Tieffenbach (thin sections), and J.-P. Oldra (sample preparation).

\section{References}


570 Barrat, J.A., Keller, F., Amossé, J., Taylor, R.N., Nesbitt, R.W., Hirata, T., 1996.

571 Determination of rare earth elements in sixteen silicate reference samples by ICP-MS

572 after Tm addition and ion exchange separation. Geostandards Newsletter 20, 133-139.

573 Barrat, J.A., Zanda, B., Moynier, F., Bollinger, C., Liorzou, C., and Bayon, G. 2012.

574 Geochemistry of CI chondrites: Major and trace elements, and $\mathrm{Cu}$ and $\mathrm{Zn}$ isotopes.

$575 \quad$ Geochimica et Cosmochimica Acta, 83: 79-92.

576 Bioret, F., David, L., Darboux, J.-R., Gourmelon, F., Guermeur, Y. et al. 2012. Ouessant.

577 Atlas environnemental. ISBN: 978-2-9534262-3-6. Les cahiers du CEMO, 4. hal-

$578 \quad 00797158$.

579 Bull, K.F., and McPhie, J. 2007. Fiamme textures in volcanic successions: Flaming issues of

580 definition and interpretation. Journal of Volcanology and Geothermal Research, 164:

$581 \quad 205-216$

582 Cabanis, B. 1986. Identification des séries magmatiques dans les socles métamorphiques sur

583 la base de critères géologiques, pétrographiques et géochimiques. Exemples

584 d'application dans le Massif Armoricain. Implications géodynamiques. Contribution à

585 une méthode d'étude basée sur les éléments traces. Thesis, Université Pierre et Marie

$586 \quad$ Curie, Paris.

587 Cabanis, B., and Lecolle, M. 1989. Le diagramme La/10-Y/15-Nb/8: un outil pour la

588 discrimination des séries volcaniques et la mise en évidence des processus de mélange

589 et/ou de contamination crustale. Compte Rendus de l'Académie des Sciences, Paris, II,

$590 \quad$ 309: 2023-2029.

591 Caroff, M., Labry, C., Le Gall, B., Authemayou, C., Bussin Grosjean, D., and Guillong, M.

592 2015. Petrogenesis of late-Variscan high-K alkali-calcic granitoids and calc-alkalic 
593

594

595

596

597

598

599

600

601

602

603

604

605

606

607

608

609

610

611

612

613

614

615

616

lamprophyres: the Aber-Ildut/North-Ouessant complex, Armorican massif, France. Lithos, 238: 140-155.

Caroff, M., Le Gal, X., Rolet, J., Cotten, J., and Thonon, P. 1996. Magmatisme tholeiitique continental en contexte orogénique hercynien : l'exemple du volcanisme viséen de Kerroc'h, Massif armoricain (France). Comptes Rendus de l'Académie des Sciences, Paris, II, 322: 269-275.

Caroff, M., Vidal, M., Bénard, A., and Darboux, J.-R. 2009. A late-Ordovician phreatomagmatic complex in marine soft-substrate environment: The Crozon volcanic system, Armorican Massif (France). Journal of Volcanology and Geothermal Research, 184: 351-366.

Chauris, L., 1992. Intrusions sodiques à affinité trondhjémitiques dans le Nord-Ouest de la Bretagne (France). Comptes Rendus de l'Académie des Sciences, Paris, II, 315: 705710.

Chauris, L. 1994. Notice explicative, Carte géologique de la France (1/50 000), feuille Plouarzel - Île d'Ouessant (237). Orléans, BRGM Éditions.

Coira, B., and Pérez, B. 2002. Peperitic textures of Ordovician dacitic synsedimentary intrusions in Argentina's Puna Highland: clues to emplacement conditions. Journal of Volcanology and Geothermal Research, 114: 165-180.

Cotten, J., Le Dez, A., Bau, M., Caroff, M., Maury, R., Dulski, P., Fourcade, S., Bohn, M., and Brousse, R. 1995. Origin of rare-earth element and yttrium enrichments in subaerial exposed basalts: evidence from French Polynesia. Chemical Geology, 119: 115-138.

Dadd, K.A., and Van Wagoner, N.A. 2002. Magma composition and viscosity as controls on peperite texture: an example from Passamaquoddy Bay, southeastern Canada. Journal of Volcanology and Geothermal Research, 114: 63-80. 
617 Ducassou, C., Poujol M., Ruffet, G., Bruguier, O., and Ballèvre, M. 2014. Relief variation and 618 erosion of the Variscan belt: detrital geochronology of the Paleozoic sediments from the 619 Mauges unit (Armorican massif, France). Geological Society, London, Special 620 publications, 405. doi 10.1144/SP405.6

621 Darboux, J.R., and Le Gall, B. 1988. Les Montagnes Noires: Cisaillement bordier méridional 622 du bassin carbonifère de Châteaulin (Massif armoricain, France). Caractéristiques 623 structurales et métamorphiques. Geodinamica Acta, 2(3): 121-133.

624 Erkül, F., Helvacı, C., and Sözbilir, H. 2006. Olivine basalt and trachyandesite peperites 625 formed at the subsurface/surface interface of a semi-arid lake: An example from the 626 Early Miocene Bigadiç basin, western Turkey. Journal of Volcanology and Geothermal $627 \quad$ Research, 149: 240-262.

628 Galerne, C., Caroff, M., Rolet, J., and Le Gall, B. 2006. Magma-sediment mingling in an 629 Ordovician rift basin: the Plouézec-Plourivo half-graben, Armorican Massif, France. 630 Journal of Volcanology and Geothermal Research, 155: 164-178.

631 Gapais, D., and Le Corre, C. 1980. Is the Hercynian belt of Brittany a major shear zone ? $632 \quad$ Nature, 288: 574-576.

633 Gumiaux, C., Gapais, D., Brun, J.-P., Chantraine, J., and Ruffet, G. 2004. Tectonic history of 634 the Armorican Shear Belt (Brittany, France). Geodynamica Acta, 17: 289-307.

635 Jutzeler, M., McPhie, J., and Allen, S.R. 2014. Submarine eruption-fed and resedimented 636 pumice-rich facies: the Dogashima Formation (Izu Peninsula, Japan). Bulletin of 637 Volcanology, 76:867. doi:10.1007/s00445-014-0867-x.

638 Lahaye, Y., Blais, S., Auvray, B., and Ruffet, G. 1995. Le volcanisme fissural paléozoïque du 639 domaine nord-armoricain. Bulletin de la Société géologique de France, 166(5): 601-612. 640 Le Gall, B. 1992. Notice explicative, Carte géologique de la France (1/50 000), feuille Gourin 641 (311). Orléans, BRGM Éditions. 
642 Le Gall, B., Authemayou, C., Ehrhold, A., Paquette, J.-L., Bussien, D., Chazot, G., Aouizerat, 643 A., and Pastol, Y. 2014. LiDAR offshore structural mapping and U/Pb zircon/monazite 644 dating of Variscan strain in the Léon metamorphic domain, NW Brittany. 645 Tectonophysics, 630: 236-250.

646 Le Hérissé, A., and Plaine, J. 1982. Volcanisme basique dans le Carbonifère inférieur du 647 Synclinorium de Laval (Massif armoricain, France). Comptes Rendus de l'Académie 648 des Sciences, Paris, II, 294: 1199-1202.

649 Le Maitre, R.W., Streckeisen, A., Zanettin, B., Le Bas, M.J., Bonin, B., Bateman, P., Bellieni, 650 G., Dudek, A., Efremova, S., Keller, J., Lamere, J., Sabine, P.A., Schmid, R., Sorensen, 651 H., and Woolley, A.R. 2002. Igneous Rocks: A Classification and Glossary of Terms, 652 Recommendations of the International Union of Geological Sciences, Subcommission of the Systematics of Igneous Rocks. Cambridge University Press.

654 Ludwig, K. R. 2008. User's manual for Isoplot 3.70, a geochronological toolkit for Microsoft Excel. Berkeley Geochronology Center Special Publication, 4.

Macpherson, C.G., Dreher, S.T., and Thirlwall, M.F. 2006. Adakites without slab melting: high pressure differentiation of island arc magma, Mindanao, the Philippines. Earth ans Planetary Sciences Letters, 243(3-4): 581-593.

Marcoux, E., Cocherie, A., Ruffet, G., Darboux, J.R., and Guerrot, C. 2009. Géochronologie revisitée du dôme du Léon (Massif armoricain, France). Géologie de la France, 1: 19-40.

661 Martin, U., and Németh, K. 2007. Blocky versus fluidal peperite textures developed in 662 volcanic conduits, vents and crater lakes of phreatomagmatic volcanoes in Mio/Pliocene 663 volcanic fields of Western Hungary. Journal of Volcanology and Geothermal Research, 664 159: $164-178$. 
665 McPhie, J., and Allen, R.L. 1992. Facies architecture of mineralized submarine volcanic

666 sequences: Cambrian Mount Read Volcanics, Western Tasmania. Economic Geology,

$667 \quad 87: 587-596$.

668 Moyen, J.-F. 2009. High Sr/Y and La/Yb ratios: The meaning of the "adakitic signature".

$669 \quad$ Lithos, 112: 556-574.

670 Paquette, J.L., Balé, P., Ballèvre, M., and Georget, Y. 1987. Géochronologie et géochimie des

671 éclogites du Léon: nouvelles contraintes sur l'évolution géodynamique du Nord-Ouest

672 du Massif armoricain. Bulletin de Minéralogie, 110: 683-696.

673 Pearce, T.H., Gorman, B.E., and Birkett, T.C. 1977. The relationship between major element

674 chemistry and tectonic environment of basic and intermediate volcanic rocks. Earth and

$675 \quad$ Planetary Science Letters, 36(1): 121-132.

676 Rolet, J. 1984. Grabens losangiques (pull-apart) en régime de décrochement. Le rôle des

677 coulissements hercyniens dans l'individualisation des bassins carbonifères du Massif

678 armoricain. Bulletin de la Société géologique du Nord, 103: 209-220.

679 Rolet, J., Le Gall, B., Darboux, J.R., Thonon, P., and Gravelle, M. 1986. L'évolution

680 géodynamique dévono-carbonifère de l'extrémité occidentale de la chaîne hercynienne

681 d'Europe sur le transect Armorique-Cornwall. Bulletin de la Société Géologique de

682 France, 8, 43-54.

683 Saadat, S., Karimpour, M.H., and Stern, C. 2010. Petrochemical characteristics of Neogene

684 and Quaternary alkali olivine basalts from the Western Margin of the Lut Block, Eastern

685 Iran. Iranian Journal of Earth Sciences, 2: 87-106.

686 Schaltegger, U., Schneider, J.-L., Maurin, J.-C., and Corfu, F. 1996. Precise U - Pb

687 chronometry of 345-340 Ma old magmatism related to syn-convergence extension in the

688 Southern Vosges (Central Variscan Belt). Earth and Planet Science Letters, 144(3-4):

$689 \quad 403-419$. 
690 Schulz, B. 2013. Monazite EMP-Th-U-Pb age pattern in Variscan metamorphic units in the 691 Armorican Massif (Brittany, France). German Journal of Geosciences, 164: 313-335.

692 Schulz, B., Krenn, E., Finger, F., Bratz, H., and Klemd, R. 2007. Cadomian and Variscan 693 metamorphic events in the Léon Domain (Armorican massif, France): P-T data and 694 EMP monazite dating. In The evolution of the Rheic ocean from Avalonian-Cadomian 695 active margin to Alleghenian-Variscan collision. Edited by U. Linneman, R. Nance and 696 P. Kraft. Geological Society of America Special Papers, 423: 267-285.

697 Shearer, C.K., and Papike, J.J. 1989. Is plagioclase removal responsible for the negative $\mathrm{Eu}$ 698 anomaly in the source regions of mare basalts? Geochimica et Cosmochimica Acta, 53: 3331-3336.

Skilling, I.P., White, J.D.L., and McPhie, J. 2002. Peperite: a review of magma-sediment mingling. Journal of Volcanology and Geothermal Research, 114: 1-17.

Sláma, J. et al. 2008. Plesovice zircon - A new natural reference material for U-Pb and Hf isotopic microanalysis. Chemical Geology, 249(1-2): 1-35.

Streckeisen, A.L. 1976. To each plutonic rock its proper name. Earth Science Reviews, 12: 1705 33.

Streckeisen, A.L., and Le Maitre, R.W. 1979. A chemical approximation to the modal QAPF classification of the igneous rocks. Neues Jahrbuch für Mineralogie, Abhandlungen, 136: $169-206$.

Sylvester, P.J. 1998. Post-collisional strongly peraluminous granites. Lithos, 45: 29-44.

710 van Achterberg, E., Ryan, C.G., Jackson, S.E., and Griffin, W. 2001. Data reduction software 711 for LA-ICP-MS. In Laser Ablation- ICPMS in the Earth Science: Principles and 712 Applications. Edited by P. Sylvester. Mineralogical Association of Canada, Short 713 Course Series, Ottowa, Ontario, Canada, 29: 239-243 
714 White, J.D.L., McPhie, J., and Skilling, I.P. 2000. Peperite: a useful genetic term. Bulletin of

$715 \quad$ Volcanology, 62: 65-66.

716 White, W.M., and Patchett, J. 1984. Hf-Nd-Sr isotopes and incompatible element abundances

717 in island Arcs: implications for magma origins and crust-mantle evolution. Earth and

$718 \quad$ Planetary Sciences Letters, 67: 167-185.

719 Yang, Z.-F. 2012. Combining quantitative textural and geochemical studies to understand the solidification processes of a granite porphyry: Shanggusi, East Qinling, China. Journal of Petrology, 53(9): 1807-1835.

722

723

Figure captions

724

725

Fig. 1. Geological features of the western extremity of the Léon Domain. (a) Shear-zone patterns, structural domains and Tournaisian-Visean basins in the Armorican Massif. (b)

Ouessant geological context. The map of the offshore studied area is from Le Gall et al. (2014). COSZ, NASZ, NOSZ, and PGSZ are for Central Ouessant, North Armorican, North Ouessant, and Porspoder-Guissény shear zones, respectively.

730

Fig. 2. Geological sketch of South Ouessant Island, based on Chauris (1994) and Bioret et al. (2012). The reader could refer to Caroff et al. (2015) about the North Ouessant area.

Fig. 3. U-Pb analyses and ages of the porphyritic monzogranite 14DB01 given with 1 sigma

735 level error (ellipses and error bars): a) Tera-Wasserburg diagram intercept age (line and 736 frame) based on the black ellipses. Dotted ellipses are disregarded analyses. b) Weighted

737 average ${ }^{206} \mathrm{~Pb} /{ }^{238} \mathrm{U}$ ages with the resultant age. Details in Table S1. c) Representative 738 cathodoluminescence images of sample 14DB01 zircons, with localisation and number of the 
739 analytical spots (see Table $\mathrm{S} 1$ ), with their resultant ${ }^{206} \mathrm{~Pb} /{ }^{238} \mathrm{U}$ ages and 1 sigma error in Ma.

740 Scale bar represents 50 microns.

741

742

743

744

745

746

747

748

749

750

751

752

753

754

755

756

757

758

759

760 Fig. 7. Photomicrographs of the four main types of (more or less metamorphized) magmatic

761

762

Fig. 4. Emplacement structures of the main magmatic bodies. (a) Amphibolitized pillow lava, Porz Doun. (b) (c) Details of the precedent photograph. Coin for scale. (d) Amphibolitized volcaniclastic succession, Porz an Ejen. Mace handle for scale. (e) Detail of the precedent photograph. (f) Micaschist/trondhjemite contacts in the Lampaul Bay. Pencil for scale. (g) Amoeboid porphyritic monzogranite in micaschists, Porz Doun. Coin for scale. (h) Micaschists (grey) / leucogranite (yellow) contacts, south of Lampaul Bay. Coin for scale.

Fig. 5. Peperitic facies. (a) Frozen crystal-bearing monzogranitic plume descending into metasediment (micaschist), Croix de Saint-Paul. Inset: detail. Coin for scale. (b)

Metasediment loaded with monzogranite-derived K-feldspar crystals, Porz an Ejen. Pencil for scale. (c) Monzogranitic breccias bearing metasedimentary fiammes and graphite clasts, Porz an Ejen. Coin for scale. (d) Fiamme-bearing breccia, Porz an Ejen. Encircled coin for scale.

Fig. 6. Photographic assemblage showing intimate mingling of porphyritic monzogranite and graphite-bearing micaschist, east of Porz an Ejen. We can also observe lenses of micaschist, similar to the fiammes of Fig. $5 \mathrm{c}$, d, becoming detached from the main metasedimentary bodies. rocks from South Ouessant (crossed nicols). (a) Amphibolite (ancient basaltic pillow lava) OS8. (b) Microtrondhjemite OSB30. (c) Monzogranite 14DB01. (d) Syenogranite OS3c. Bi: 
763 biotite; $\mathrm{Hb}$ : hornblende; Mi: microcline; $\mathrm{Mu}$ : muscovite ; My : myrmekite ; Pl: plagioclase;

764 Q: quartz.

765

766

Fig. 8. Drawings of photomicrographs of mingled structures. (a) Monzogranitic K-feldspar

767 (Afs) megacrysts embedded within graphite-bearing poikiloblastic micaschist. Location of sample OSB16a in Fig. 6 (Porz an Ejen). (b) Microtexture of lobed contacts between coarse-

769 grained tourmaline-bearing leucogranite and fine-grained metasediment. There is no clear

770 limit between both lithologies, but a 2-4 mm-large biotite-rich transition zone. Sample OSB5

771 is positioned in Fig. 5a (Croix de Saint-Paul).

772

773

Fig. 9. Major element diagrams for samples from South Ouessant and other Central

774 Armorican Carboniferous basins (Morlaix: Cabanis 1986 and Chauris 1992; North

775 Châteaulin: Caroff et al. 1996; South Châteaulin: Le Gall 1992; Laval: Bonnefoy 1999,

776 unpublished Master report), together with Saint-Malo dolerites (Lahaye et al. 1995). Analyses

777 in Table 1 and $\mathrm{S} 2$. (a) (b) $\mathrm{TiO}_{2}$ and $\mathrm{P}_{2} \mathrm{O}_{5}$ vs. $\mathrm{SiO}_{2}$ diagrams. (c) $\mathrm{MgO}-\mathrm{FeO} *-\mathrm{Al}_{2} \mathrm{O}_{3}$ triangular

778 discrimination diagram of Pearce et al. (1977), for mafic samples. (d) $\mathrm{K}_{2} \mathrm{O} / \mathrm{Na}_{2} \mathrm{O}$ vs. $\mathrm{SiO}_{2}$

779 diagram, with the high-silica adakite (HSA) field of Moyen (2009).

780

781 Fig. 10. Trace element diagrams for samples from South Ouessant and other Central

782 Armorican Carboniferous basins (Morlaix: Cabanis 1986; North Châteaulin: Caroff et al.

7831996 and this study; Laval: Bonnefoy 1999, unpublished Master report, and this study),

784 together with Saint-Malo dolerites (Lahaye et al. 1995). Analyses in Table 1 and S2. (a)

$785 \mathrm{La} / \mathrm{Eu}$ and $\mathrm{La} / \mathrm{Tb}$ vs. $\mathrm{SiO}_{2}$ diagrams. (b) $\mathrm{La} / 10-\mathrm{Y} / 15-\mathrm{Nb} / 8$ triangular discrimination diagram

786 of Cabanis and Lecolle (1989), for mafic samples. (c) (d) $\mathrm{Sr} / \mathrm{Y}$ and $\mathrm{La} / \mathrm{Yb}$ vs. $\mathrm{SiO}_{2}$ diagram,

787 with the high-silica adakite (HSA) fields of Moyen (2009). 
789 Fig. 11. CI-chondrite normalized trace element patterns of rocks from South Ouessant and 790 other Central Armorican Carboniferous basins, together with Saint-Malo dolerites (references 791 as in Fig. 10). Analyses in Table 1 and S2. Normalization values: Barrat et al. 2012. (a) Mafic 792 rocks. (b) South Ouessant silicic rocks and North Châteaulin basalt and andesite.

793

794 Fig. 12. $\varepsilon_{\mathrm{Nd}}^{\mathrm{t}}$ Vs. initial ${ }^{87} \mathrm{Sr} /{ }^{86} \mathrm{Sr}$ isotope diagram showing South Ouessant and North 795 Châteaulin samples, compared with the Aber-Ildut/North-Ouessant (AI-NO) field (Caroff et 796 al. 2015). Symbols as in Fig. 11.

797

798

Fig. 13. Block diagram showing a 3D-restored view of the South Ouessant Visean basin.

799

800 Fig. 14. Restored lithosphere/asthenosphere block diagram of the Central Armorican Domain 801 at 340-330 Ma. Orange-colored dashed lines: possible extension of the Visean basins; green802 colored dashed lines and arrows: future Variscan shear zones.

803 


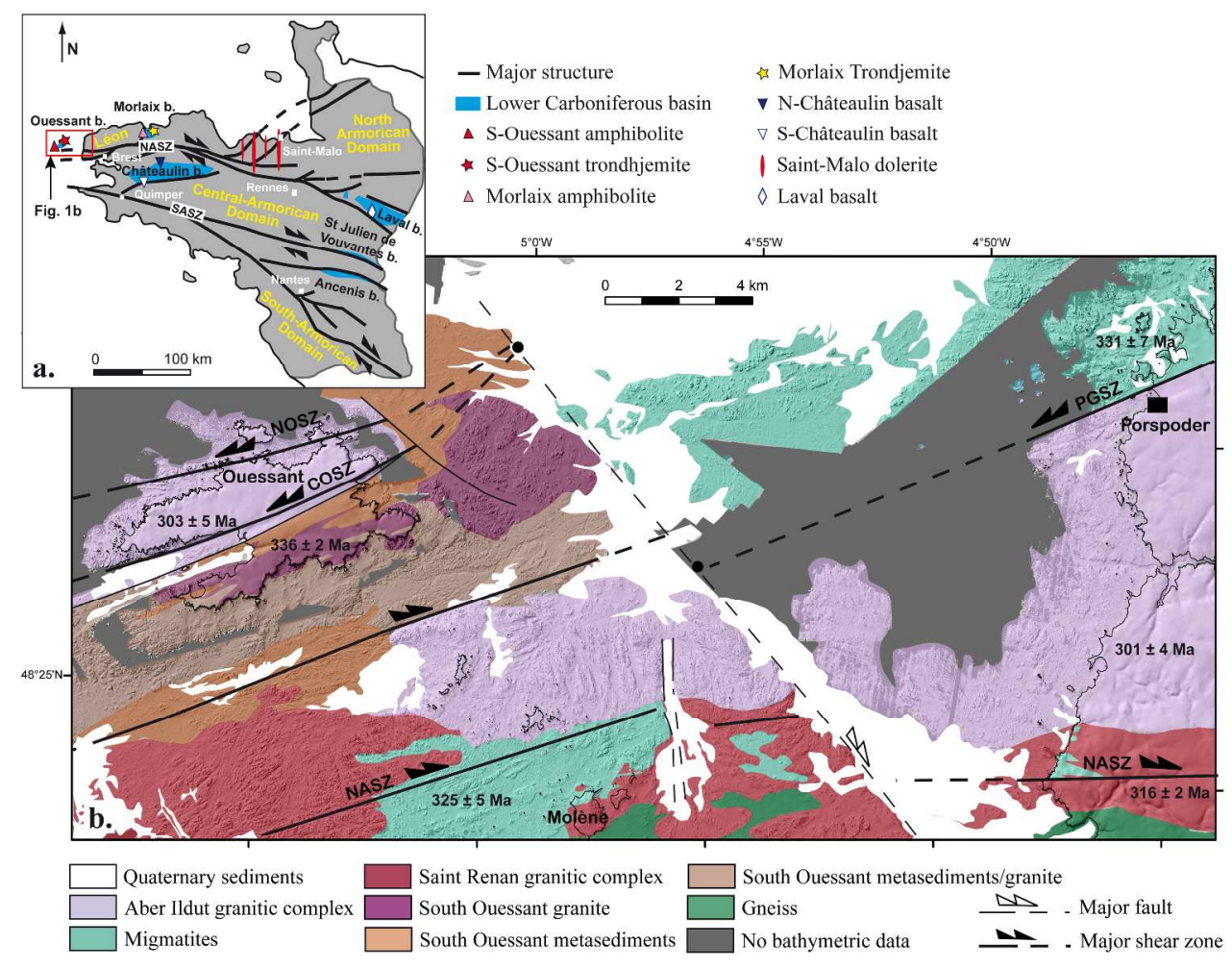

Fig. 1

$299 \times 225 \mathrm{~mm}(300 \times 300 \mathrm{DPI})$ 


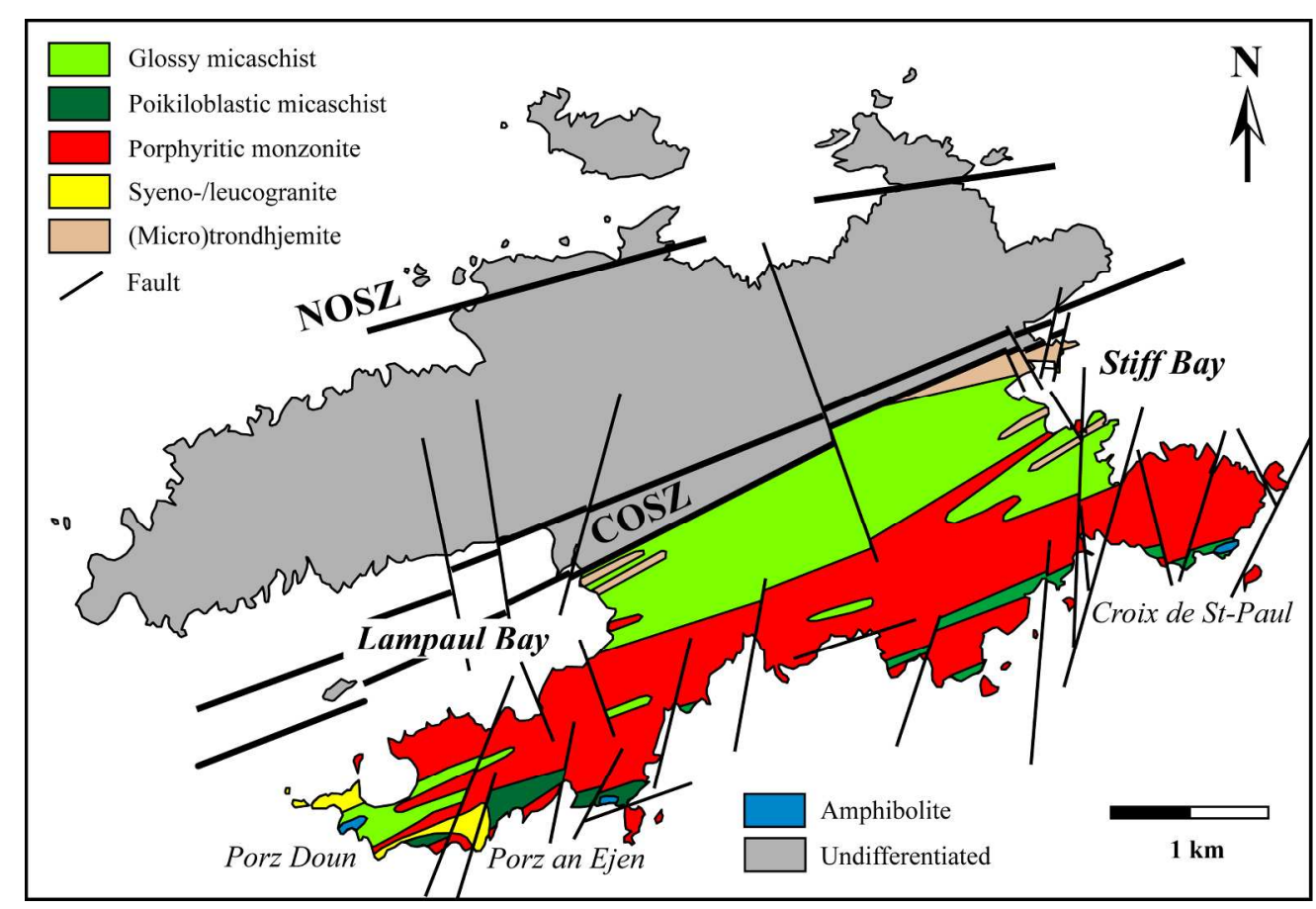

Fig. 2

$210 \times 144 \mathrm{~mm}(300 \times 300$ DPI $)$ 

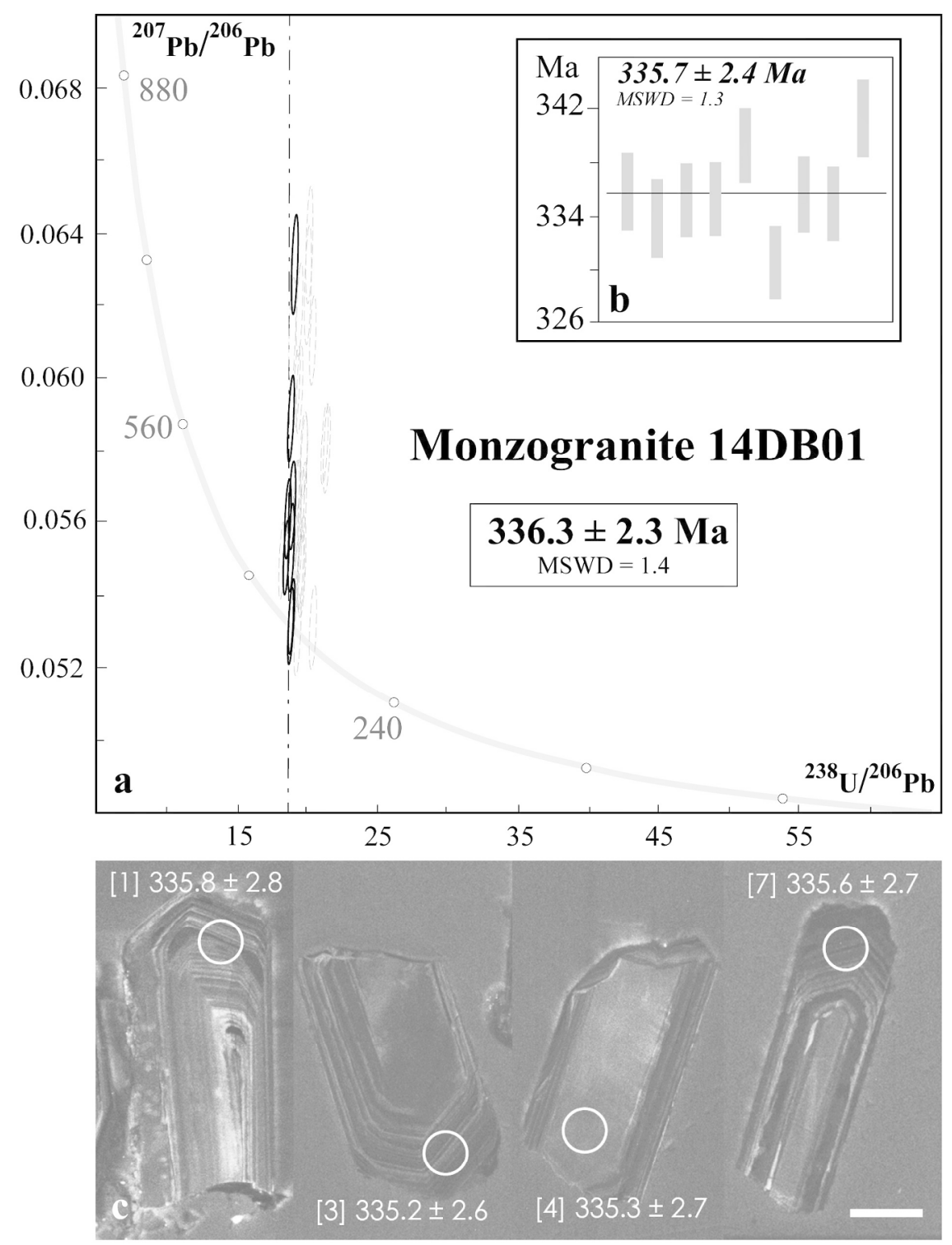

Fig. 3 rev

$168 \times 223 \mathrm{~mm}(300 \times 300 \mathrm{DPI})$ 

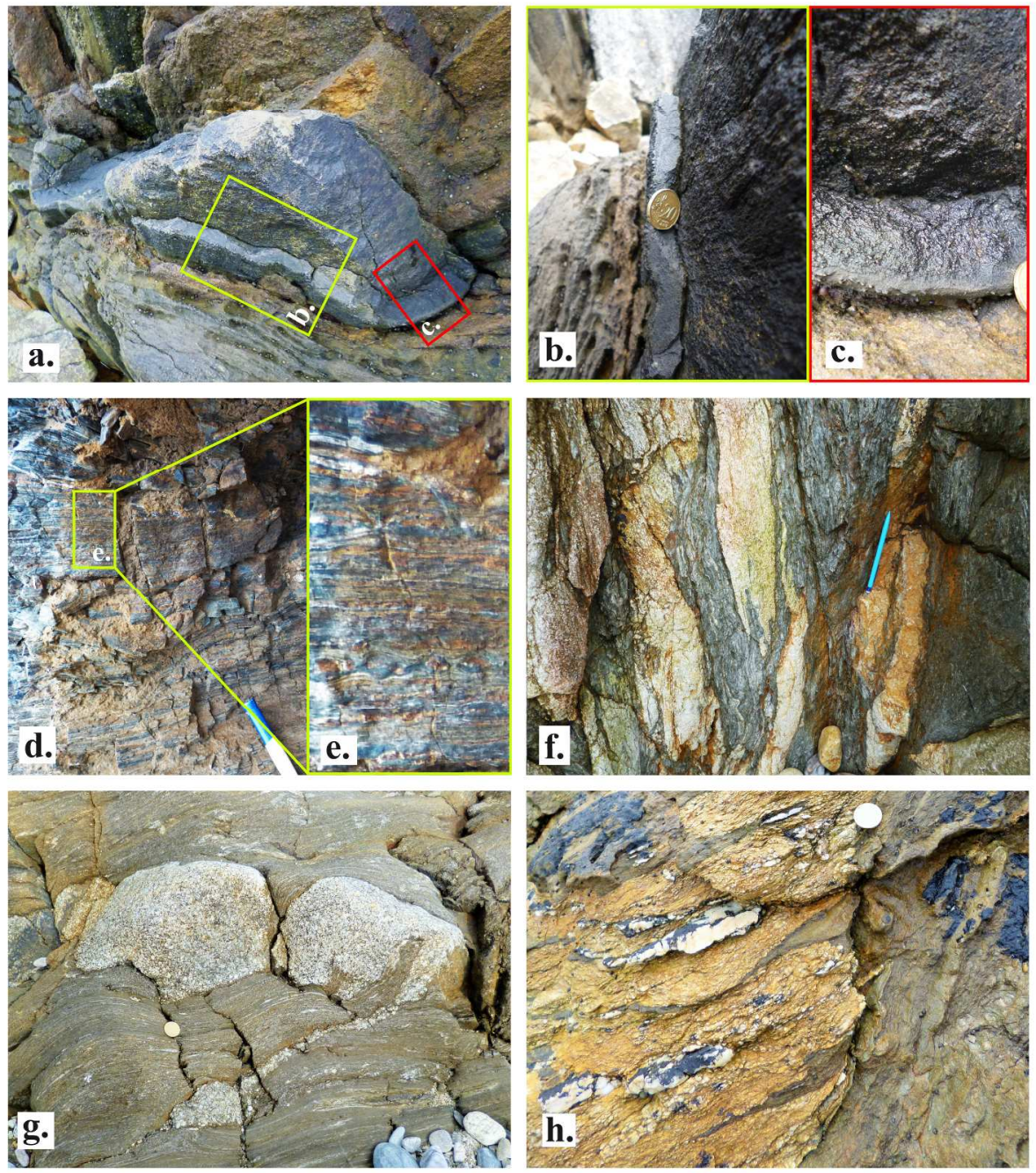

Fig. 4

$233 \times 243 \mathrm{~mm}(300 \times 300$ DPI $)$ 

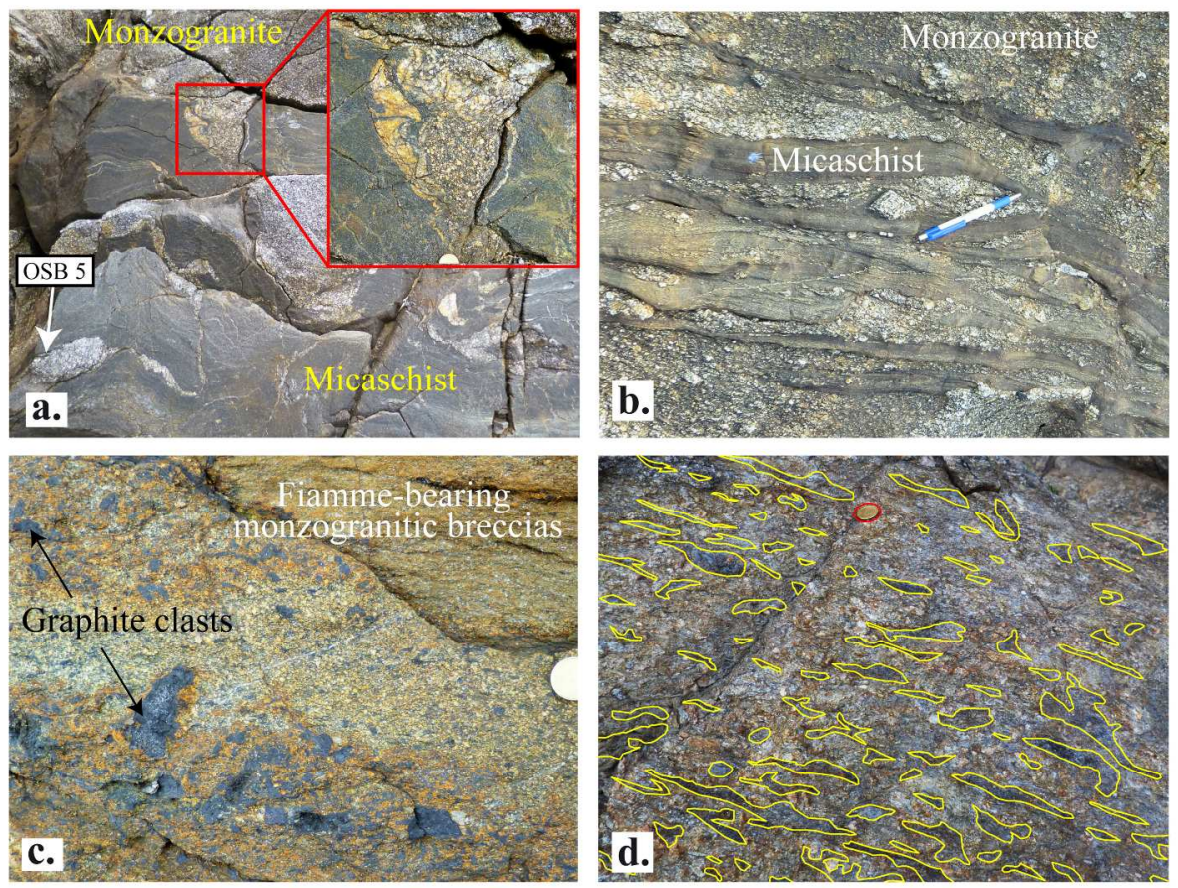

Fig. 5

$233 \times 162 \mathrm{~mm}(300 \times 300$ DPI $)$ 


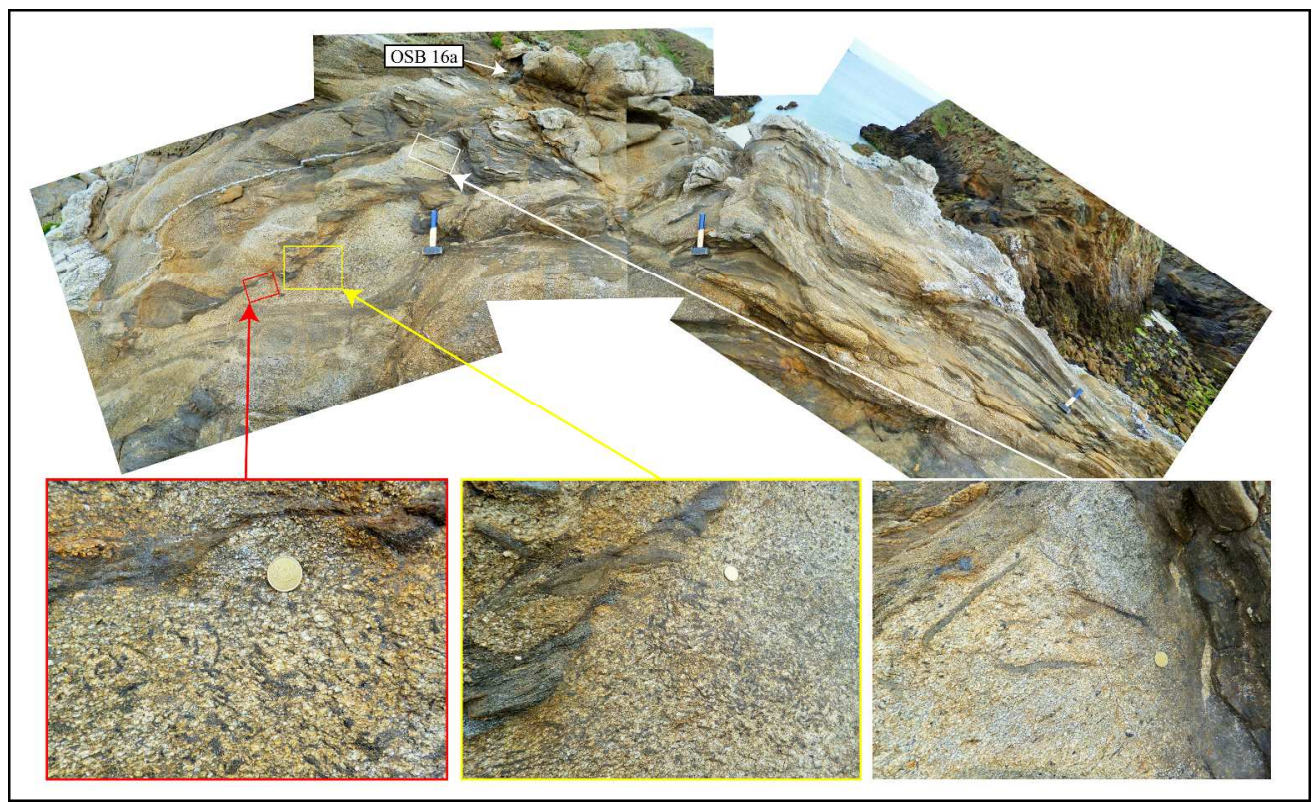

Fig. 6

$397 \times 241 \mathrm{~mm}(300 \times 300$ DPI) 

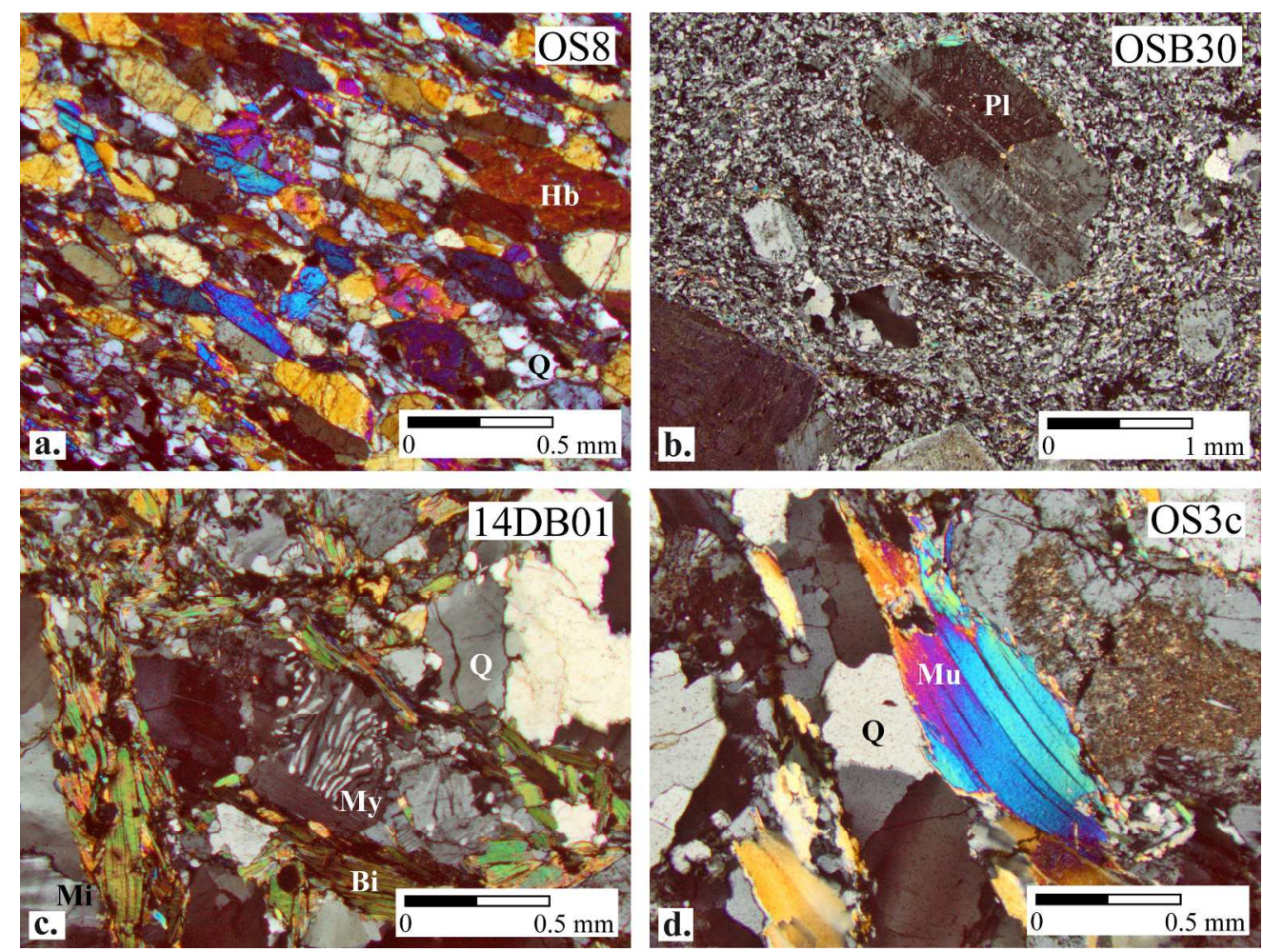

Fig. 7 rev

$231 \times 174 \mathrm{~mm}(300 \times 300 \mathrm{DPI})$ 

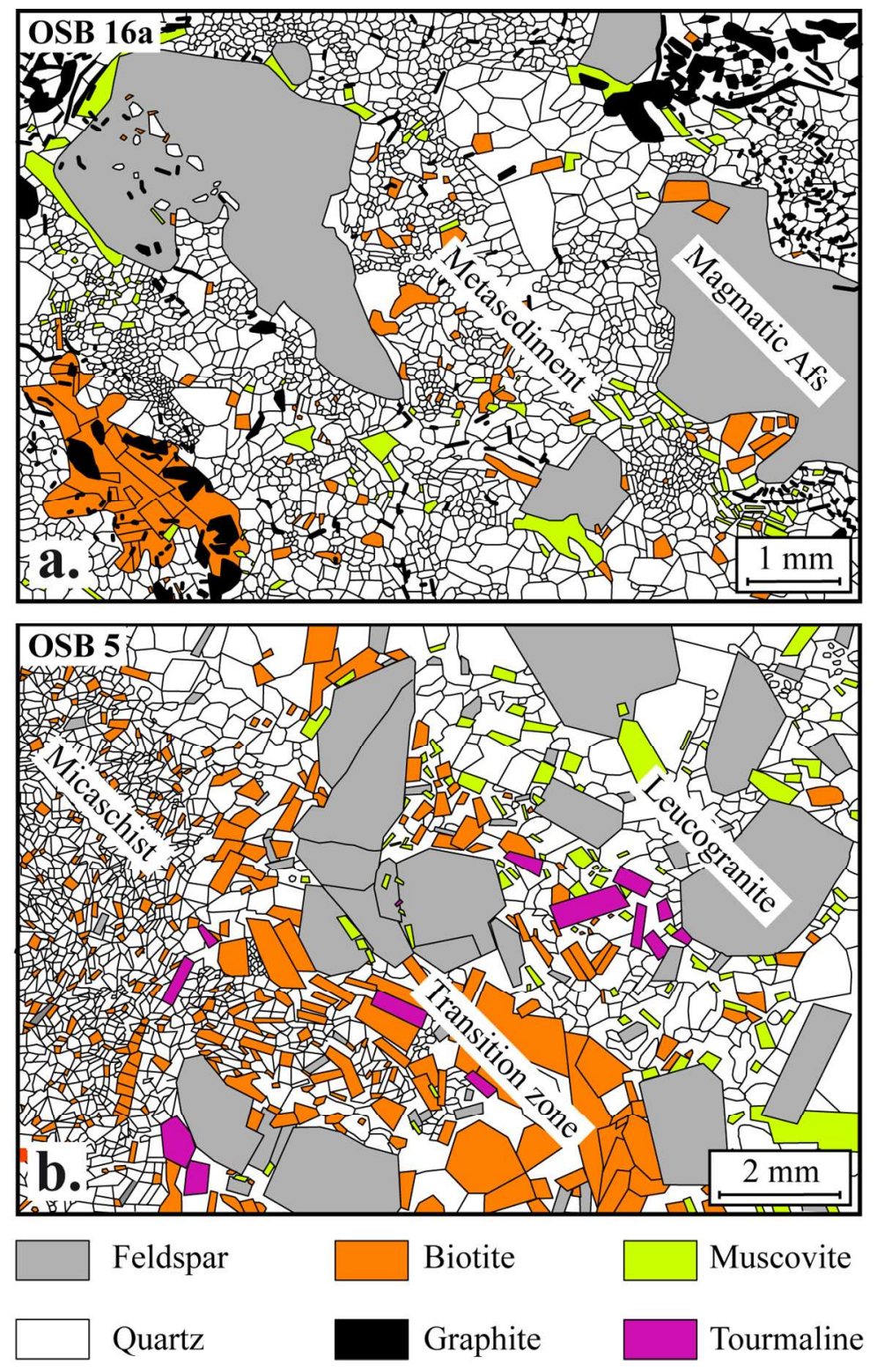

Fig. 8 rev

$144 \times 169 \mathrm{~mm}(300 \times 300$ DPI $)$ 

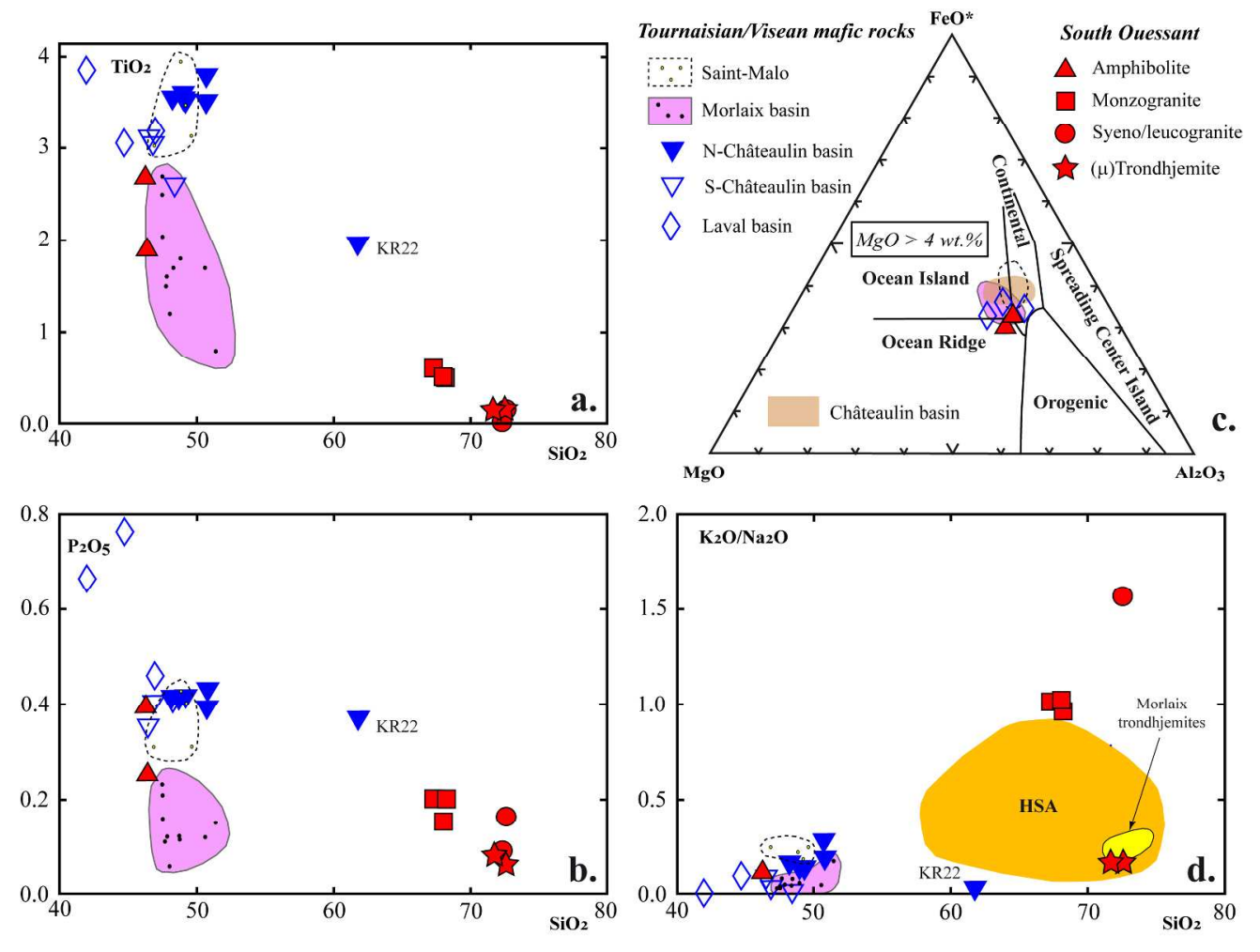

Fig. 9 rev

$244 \times 185 \mathrm{~mm}(300 \times 300 \mathrm{DPI})$ 

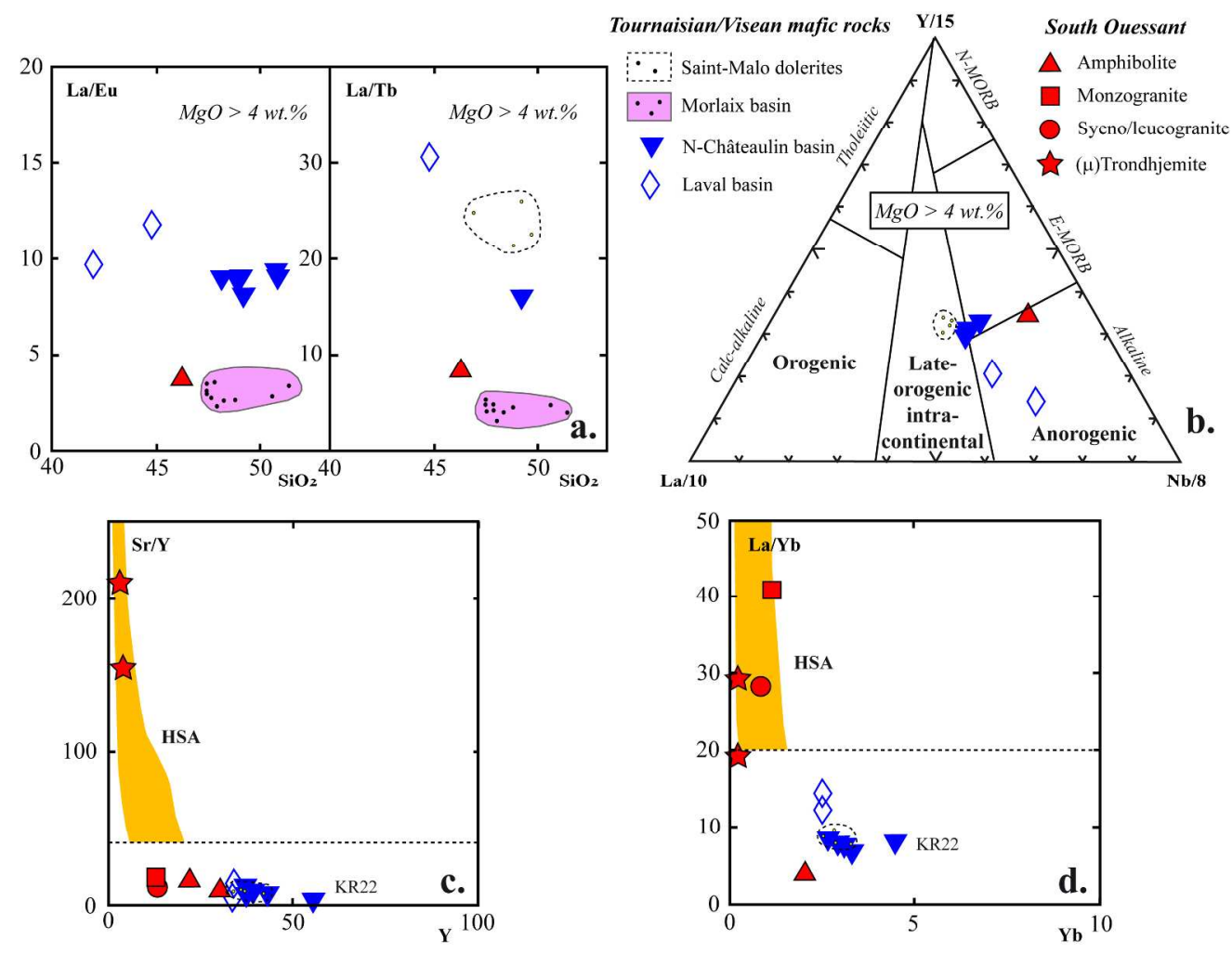

Fig. 10 rev

$238 \times 185 \mathrm{~mm}(300 \times 300$ DPI $)$ 


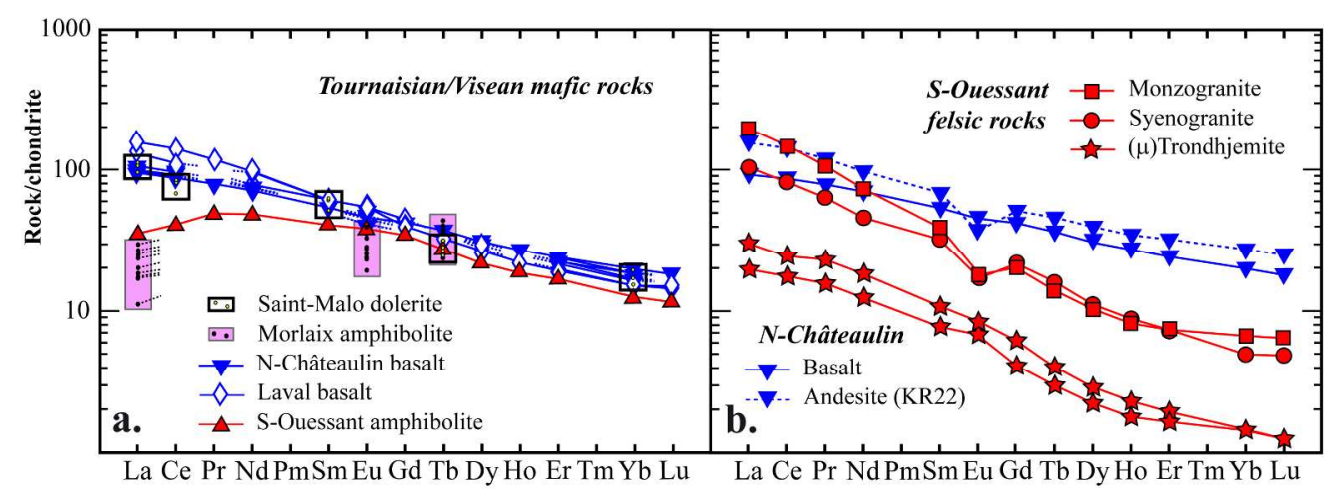

Fig. 11 rev

$233 \times 105 \mathrm{~mm}(300 \times 300$ DPI) 


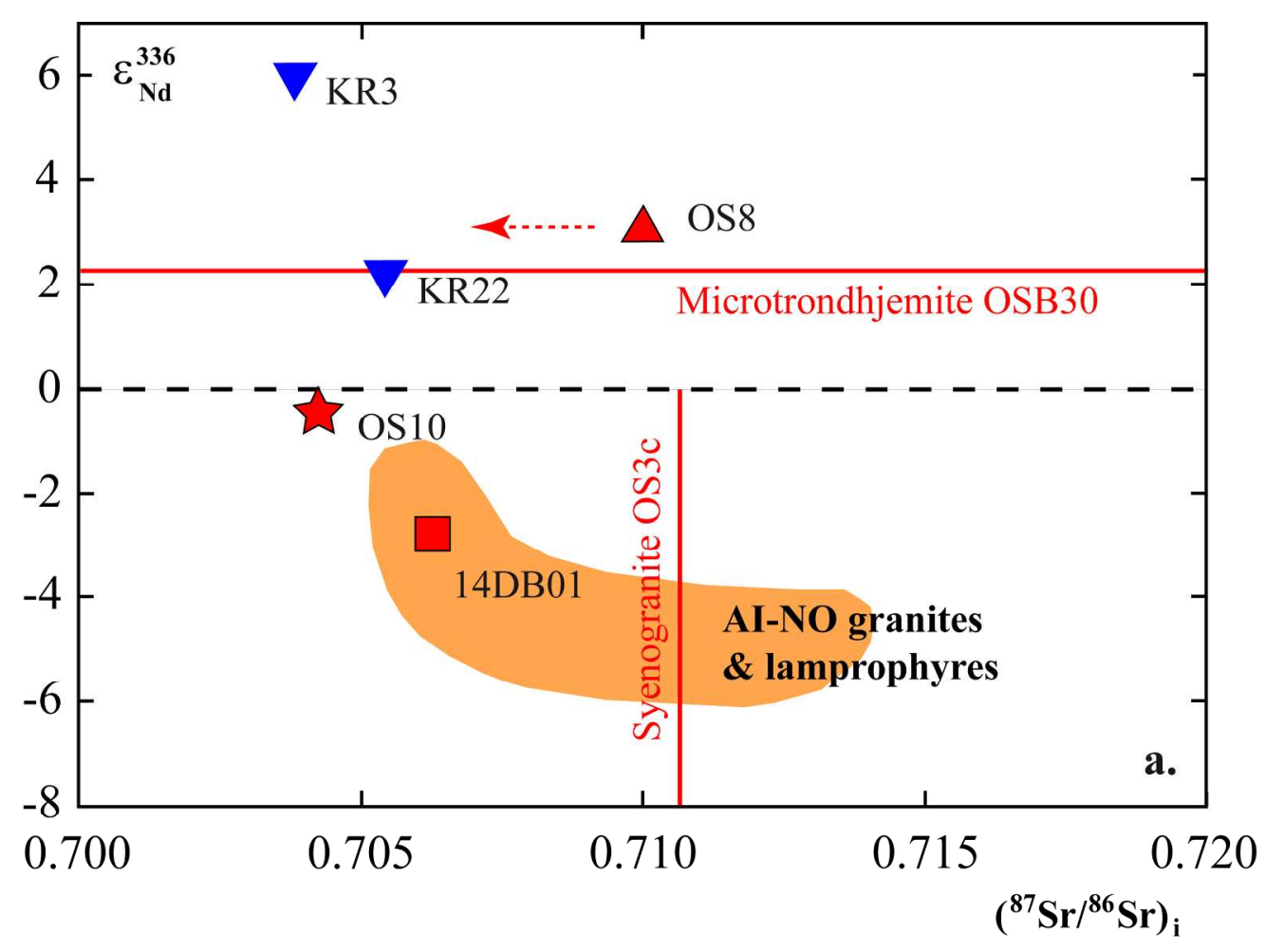

Fig. 12 rev

199x149mm (300 x 300 DPI) 


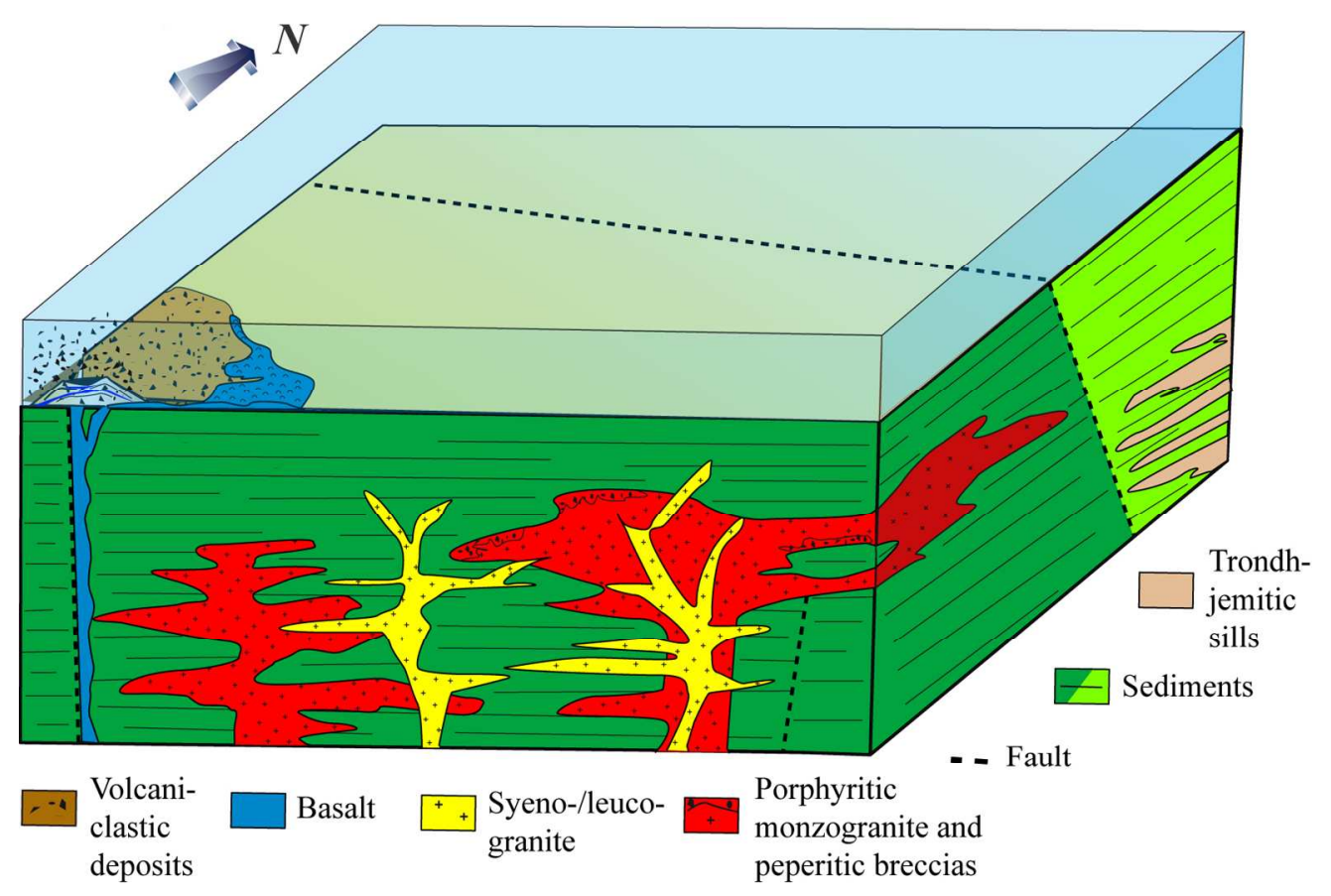

Fig. 13 rev

$144 \times 96 \mathrm{~mm}$ (300 x 300 DPI) 


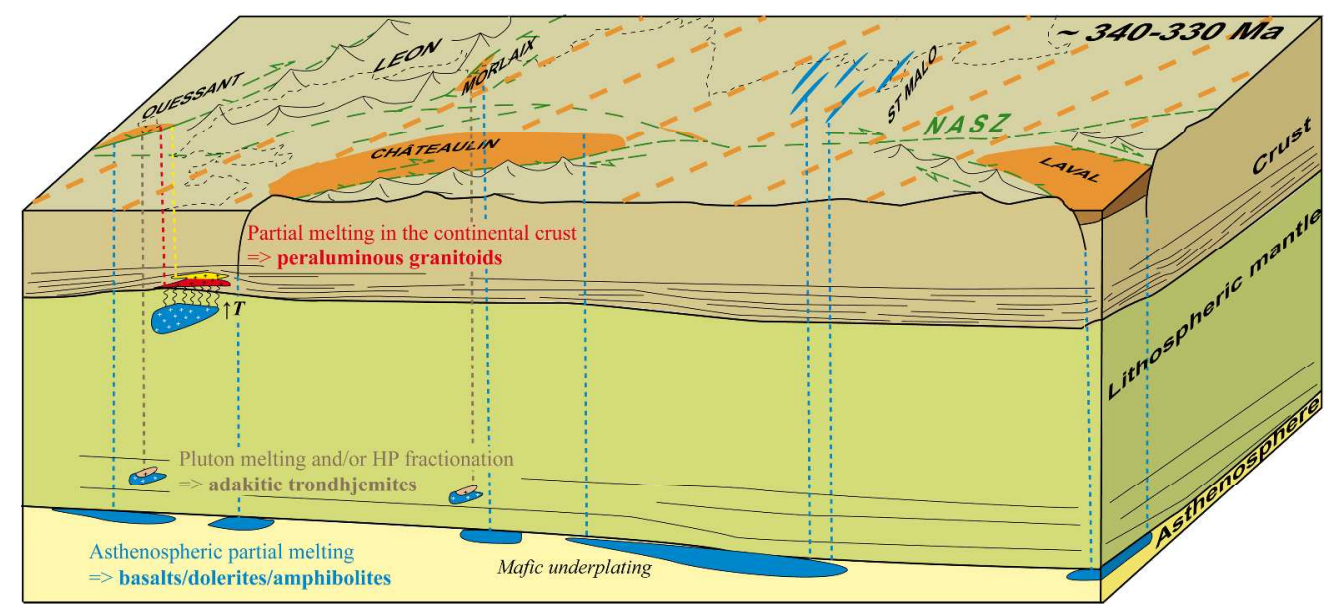

Fig. 14 rev

$298 \times 135 \mathrm{~mm}(300 \times 300$ DPI $)$ 
Table 1. Selection of major and trace element data on whole rocks.

\begin{tabular}{|c|c|c|c|c|c|c|c|c|}
\hline Sample & OS8 & LC6 & LV4 & KR3 & KR22 & 14DB01 & LC12 & LC13 \\
\hline Location & SO & SO & Laval & $\mathrm{NC}$ & $\mathrm{NC}$ & SO & SO & SO \\
\hline Type & Amph. & Amph. & Basalt & Basalt & Andes. & Mzgr. & Mzgr. & Mzgr. \\
\hline Emplacement & Pillow & Pillow & Flow & Flow & Breccia & Pluton & Pluton & Pluton \\
\hline \multicolumn{9}{|c|}{ Major elements (wt.\%) } \\
\hline $\mathrm{SiO}_{2}$ & 46.27 & 46.40 & 44.80 & 49.20 & 61.80 & 68.00 & 67.30 & 68.20 \\
\hline $\mathrm{TiO}_{2}$ & 2.68 & 1.89 & 3.05 & 3.51 & 1.96 & 0.51 & 0.60 & 0.50 \\
\hline $\mathrm{Al}_{2} \mathrm{O}_{3}$ & 15.44 & 16.00 & 14.45 & 13.40 & 13.40 & 15.80 & 15.20 & 15.45 \\
\hline $\mathrm{Fe}_{2} \mathrm{O}_{3}$ tot & 12.12 & 11.70 & 12.70 & 13.82 & 7.20 & 3.20 & 3.20 & 3.18 \\
\hline $\mathrm{MnO}$ & 0.14 & 0.19 & 0.15 & 0.20 & 0.07 & 0.04 & 0.05 & 0.05 \\
\hline $\mathrm{MgO}$ & 7.06 & 8.40 & 9.30 & 5.78 & 2.41 & 1.32 & 1.50 & 1.60 \\
\hline $\mathrm{CaO}$ & 9.16 & 11.70 & 7.25 & 9.66 & 3.75 & 2.25 & 1.85 & 2.25 \\
\hline $\mathrm{Na}_{2} \mathrm{O}$ & 2.73 & $\sim 2.5$ & 1.78 & 2.48 & 5.90 & 3.60 & 3.90 & 3.85 \\
\hline $\mathrm{K}_{2} \mathrm{O}$ & 0.33 & $<0.5$ & 0.16 & 0.34 & 0.20 & 3.68 & 3.95 & 3.70 \\
\hline $\mathrm{P}_{2} \mathrm{O}_{5}$ & 0.39 & 0.25 & 0.76 & 0.40 & 0.37 & 0.15 & 0.20 & 0.20 \\
\hline LOI & 1.24 & - & 5.10 & 1.21 & 1.64 & 0.85 & 1.80 & 0.95 \\
\hline Total & 97.58 & - & 99.50 & 100.00 & 98.70 & 99.40 & 99.55 & 99.93 \\
\hline \multicolumn{9}{|c|}{ Trace elements (ppm) } \\
\hline $\mathrm{Li}$ & 50.5 & 27.0 & 36.9 & 32.3 & 17.6 & 140 & - & - \\
\hline $\mathrm{Be}$ & 1.3 & - & 1.3 & 1.4 & 3.8 & 6.5 & - & - \\
\hline $\mathrm{Rb}$ & 9 & - & 2 & 13 & 4 & 167 & - & - \\
\hline Cs & 0.67 & - & 0.97 & 8.34 & 1.86 & 15.2 & - & - \\
\hline $\mathrm{Sr}$ & 297 & 343 & 512 & 304 & 176 & 236 & - & - \\
\hline $\mathrm{Ba}$ & 18 & 77 & 205 & 209 & 68 & 726 & - & - \\
\hline $\mathrm{Sc}$ & 28 & - & 26 & 33 & 22 & 8 & - & - \\
\hline V & 276 & 303 & 245 & 352 & 165 & 46.1 & - & - \\
\hline $\mathrm{Cr}$ & 62.5 & 336 & 429 & 117 & 34.5 & 21.5 & - & - \\
\hline Co & 50 & 51 & 52 & 39 & 15 & 7 & - & - \\
\hline $\mathrm{Ni}$ & 49.7 & 89.0 & 227 & 76.1 & 12.4 & 11.5 & - & - \\
\hline $\mathrm{Cu}$ & 4.7 & 10.0 & 71.8 & 125 & 21.7 & 7.5 & - & - \\
\hline $\mathrm{Zn}$ & 164 & 158 & 111 & 125 & 93 & 80 & - & - \\
\hline Y & 30 & 22 & 34 & 43 & 56 & 13 & - & - \\
\hline $\mathrm{Zr}$ & 36 & - & 344 & 274 & 383 & 188 & - & - \\
\hline $\mathrm{Hf}$ & 1.2 & - & 6.7 & 6.1 & 9.0 & 4.9 & - & - \\
\hline $\mathrm{Nb}$ & 25 & - & 83 & 30 & 45 & 9 & - & - \\
\hline $\mathrm{Ta}$ & 1.2 & - & 5.4 & 2.1 & 3.2 & 0.6 & - & - \\
\hline W & 14.1 & - & 0.6 & 0.7 & 1.9 & 2.0 & - & - \\
\hline $\mathrm{Ga}$ & 23 & - & 22 & 26 & 17 & 24 & - & - \\
\hline $\mathrm{Pb}$ & 59.6 & 13.0 & 1.6 & 1.1 & 3.7 & 31.4 & - & - \\
\hline $\mathrm{La}$ & 8.2 & - & 36.5 & 21.5 & 36.3 & 46.1 & - & - \\
\hline $\mathrm{Ce}$ & 24.1 & - & 83.0 & 51.7 & 83.9 & 88.6 & - & - \\
\hline $\operatorname{Pr}$ & 4.4 & - & 10.5 & 7.1 & 10.6 & 9.6 & - & - \\
\hline $\mathrm{Nd}$ & 22.2 & - & 44.6 & 32.1 & 44.4 & 33.8 & - & - \\
\hline $\mathrm{Sm}$ & 6.1 & - & 9.3 & 8.1 & 10.4 & 6.0 & - & - \\
\hline $\mathrm{Eu}$ & 2.21 & - & 3.11 & 2.66 & 2.16 & 1.06 & - & - \\
\hline $\mathrm{Gd}$ & 6.99 & - & 8.26 & 8.47 & 10.42 & 4.19 & - & - \\
\hline $\mathrm{Tb}$ & 1.01 & - & 1.20 & 1.36 & 1.67 & 0.52 & - & - \\
\hline Dy & 5.43 & - & 6.63 & 7.96 & 9.86 & 2.60 & - & - \\
\hline Ho & 1.04 & - & 1.22 & 1.54 & 1.92 & 0.47 & - & - \\
\hline $\mathrm{Er}$ & 2.79 & - & 3.14 & 3.97 & 5.28 & 1.23 & - & - \\
\hline $\mathrm{Yb}$ & 2.05 & - & 2.55 & 3.29 & 4.48 & 1.13 & - & - \\
\hline $\mathrm{Lu}$ & 0.28 & - & 0.35 & 0.44 & 0.61 & 0.16 & - & - \\
\hline Th & 1.7 & - & 3.1 & 2.1 & 7.4 & 24.7 & - & - \\
\hline $\mathrm{U}$ & 0.3 & - & 0.7 & 0.7 & 2.7 & 5.0 & - & - \\
\hline
\end{tabular}


Table1. (continued)

\begin{tabular}{|c|c|c|c|c|c|c|}
\hline Sample & OS3c & LC29 & OSB30 & OS10 & $\mathrm{LC1}$ & LC5 \\
\hline Location & SO & SO & SO & SO & SO & SO \\
\hline Type & Syenogr. & T-Leucogr. & $\mu$ Trondhj. & Trondhj. & Glossy Mic. & Poik. Mic. \\
\hline Emplacement & Pluton & Pluton & Dyke & Dyke & & \\
\hline \multicolumn{7}{|c|}{ Major elements (wt.\%) } \\
\hline $\mathrm{SiO}_{2}$ & 72.57 & 72.30 & 71.70 & 72.57 & 51.70 & 62.45 \\
\hline $\mathrm{TiO}_{2}$ & 0.16 & 0.02 & 0.16 & 0.17 & 1.05 & 0.95 \\
\hline $\mathrm{Al}_{2} \mathrm{O}_{3}$ & 13.77 & 15.20 & 16.60 & 16.10 & 26.50 & 18.50 \\
\hline $\mathrm{Fe}_{2} \mathrm{O}_{3}{ }^{\text {tot }}$ & 1.27 & 0.50 & 1.00 & 0.97 & 7.80 & 6.00 \\
\hline $\mathrm{MnO}$ & 0.01 & 0.02 & 0.01 & 0.01 & 0.15 & 0.10 \\
\hline $\mathrm{MgO}$ & 0.19 & 0.20 & 0.56 & 0.52 & 2.05 & 1.75 \\
\hline $\mathrm{CaO}$ & 1.06 & 1.00 & 1.43 & 1.26 & 0.25 & 1.05 \\
\hline $\mathrm{Na}_{2} \mathrm{O}$ & 3.04 & $\sim 3.0$ & 6.26 & 6.16 & 1.30 & 1.45 \\
\hline $\mathrm{K}_{2} \mathrm{O}$ & 4.76 & 5.40 & 1.04 & 1.05 & 4.60 & 5.65 \\
\hline $\mathrm{P}_{2} \mathrm{O}_{5}$ & 0.16 & 0.09 & 0.08 & 0.06 & 0.20 & 0.15 \\
\hline LOI & 1.01 & - & 0.98 & 1.05 & 4.45 & 1.15 \\
\hline Total & 97.99 & - & 99.83 & 99.91 & 100.05 & 99.20 \\
\hline \multicolumn{7}{|c|}{ Trace elements (ppm) } \\
\hline $\mathrm{Li}$ & 73.9 & - & 42.7 & 48.7 & - & - \\
\hline $\mathrm{Be}$ & 4.2 & 7.0 & 1.7 & 1.5 & - & - \\
\hline $\mathrm{Rb}$ & 182 & - & 17 & 21 & - & - \\
\hline Cs & 4.45 & - & 1.18 & 1.39 & - & - \\
\hline $\mathrm{Sr}$ & 169 & 126 & 648 & 609 & - & - \\
\hline $\mathrm{Ba}$ & 446 & 164 & 230 & 205 & - & - \\
\hline Sc & 3 & - & 2 & 2 & - & - \\
\hline V & 4.0 & - & 14.2 & 15.1 & - & - \\
\hline $\mathrm{Cr}$ & 4.7 & 42.0 & 11.7 & 13.7 & - & - \\
\hline Co & 1 & 6 & 2 & 2 & - & - \\
\hline $\mathrm{Ni}$ & 0.3 & 17.0 & 4.6 & 3.4 & - & - \\
\hline $\mathrm{Cu}$ & 0.4 & & 4.7 & 2.3 & - & - \\
\hline $\mathrm{Zn}$ & 31 & 22 & 30 & 36 & - & - \\
\hline Y & 13 & - & 3 & 4 & - & - \\
\hline $\mathrm{Zr}$ & 76 & - & 76 & 46 & - & - \\
\hline Hf & 2.5 & - & 2.5 & 1.9 & - & - \\
\hline $\mathrm{Nb}$ & 9 & - & 3 & 1 & - & - \\
\hline $\mathrm{Ta}$ & 0.5 & - & 0.1 & 0.1 & - & - \\
\hline W & 17.3 & - & 0.3 & 8.1 & - & - \\
\hline $\mathrm{Ga}$ & 24 & - & 25 & 18 & - & - \\
\hline $\mathrm{Pb}$ & 48.0 & 42.0 & 8.4 & 11.6 & - & - \\
\hline $\mathrm{La}$ & 23.9 & - & 4.6 & 7.0 & - & - \\
\hline $\mathrm{Ce}$ & 49.2 & - & 10.6 & 14.6 & - & - \\
\hline $\operatorname{Pr}$ & 5.9 & - & 1.4 & 2.1 & - & - \\
\hline $\mathrm{Nd}$ & 20.9 & - & 5.7 & 8.4 & - & - \\
\hline $\mathrm{Sm}$ & 4.9 & - & 1.2 & 1.6 & - & - \\
\hline $\mathrm{Eu}$ & 1.00 & - & 0.40 & 0.49 & - & - \\
\hline $\mathrm{Gd}$ & 4.46 & - & 0.83 & 1.27 & - & - \\
\hline $\mathrm{Tb}$ & 0.60 & - & 0.11 & 0.15 & - & - \\
\hline Dy & 2.84 & - & 0.56 & 0.73 & - & - \\
\hline Ho & 0.50 & - & 0.10 & 0.13 & - & - \\
\hline $\mathrm{Er}$ & 1.20 & - & 0.27 & 0.32 & - & - \\
\hline $\mathrm{Yb}$ & 0.84 & - & 0.24 & 0.24 & - & - \\
\hline $\mathrm{Lu}$ & 0.12 & - & 0.03 & 0.03 & - & - \\
\hline Th & 13.5 & - & 1.0 & 1.1 & - & - \\
\hline $\mathrm{U}$ & 8.0 & - & 0.6 & 0.7 & - & - \\
\hline
\end{tabular}

Amph.: amphibolite; Andes.: andesite; Mzgr.: monzogranite; Syenogr.: syenogranite; T-Leucogr.: tourmaline-bearing leucogranite; $(\mu)$ Trondhj.: (micro)trondhjémite ; (Poik.) Mic.: (poikiloblastic) micaschist. SO: South-Ouessant; NC: North-Châteaulin basin.

Major elements were analyzed by ICP-AES (IUEM, Brest, France) following the analytical method described by Cotten et al. (1995), except LC1, LC5, LC6, LC12, LC13 and LC29 (AAS/AES Brest, Chauris, 1994), LV4 (ICP-AES Brest, Bonnefoy, 1999: unpublished Master report), KR3 and KR22 (ICP-AES, Caroff et al., 1996); trace elements were analyzed by ICP-MS (IUEM, Brest, France) following the sample preparation and analysis method of Barrat et al. (1996), except the LC samples (AAS/AES Brest, Chauris, 1994). 
Table 2. Isotopic data on whole rock samples.

\begin{tabular}{|c|c|c|c|c|c|c|c|c|c|c|c|c|c|}
\hline Type & Sample & $\begin{array}{c}\mathrm{Rb} \\
(\mathrm{ppm})\end{array}$ & $\begin{array}{c}\mathrm{Sr} \\
(\mathrm{ppm})\end{array}$ & ${ }^{87} \mathrm{Rb} /{ }^{86} \mathrm{Sr}$ & ${ }^{87} \mathrm{Sr} /{ }^{86} \mathrm{Sr}$ & $\begin{array}{c} \pm 2 \sigma \\
\left(\mathrm{x} 10^{-6}\right)\end{array}$ & $\left({ }^{87} \mathrm{Sr} /{ }^{86} \mathrm{Sr}\right)_{\mathrm{i}}$ & $\begin{array}{c}\mathrm{Sm} \\
(\mathrm{ppm})\end{array}$ & $\begin{array}{c}\mathrm{Nd} \\
(\mathrm{ppm})\end{array}$ & ${ }^{147} \mathrm{Sm} /{ }^{144} \mathrm{Nd}$ & ${ }^{143} \mathrm{Nd} /{ }^{144} \mathrm{Nd}$ & $\begin{array}{c} \pm 2 \sigma \\
\left(\mathrm{x} 10^{-6}\right)\end{array}$ & $\overline{\varepsilon^{\mathrm{t}} \mathrm{Nd}}$ \\
\hline & & & & & & & $(t=336 \mathrm{Ma})$ & & & & & & $(t=336 \mathrm{Ma})$ \\
\hline Basalt & OS8 & 9 & 297 & 0.09 & 0.710424 & 4 & 0.71001 & 6.14 & 22.2 & 0.1673 & 0.512728 & 3 & 3.0 \\
\hline Basalt & KR3 & 13 & 304 & 0.12 & 0.704427 & 5 & 0.70386 & 8.15 & 32.1 & 0.1533 & 0.512846 & 3 & 5.9 \\
\hline Andesite & KR22 & 4 & 176 & 0.07 & 0.705779 & 4 & 0.70544 & 10.38 & 44.4 & 0.1415 & 0.512627 & 3 & 2.2 \\
\hline Monzogr. & 14DB01 & 167 & 236 & 2.05 & 0.716122 & 3 & 0.70631 & 6.00 & 33.8 & 0.1074 & 0.512300 & 5 & -2.8 \\
\hline Syenogr. & OS3c & 182 & 169 & 3.13 & 0.725639 & 4 & 0.71068 & - & - & - & - & - & - \\
\hline Trondhj. & OSB30 & 17 & 648 & 0.07 & 0.734522 & 5 & 0.73417 & 1.18 & 5.7 & 0.1248 & 0.512595 & 3 & 2.2 \\
\hline Trondhj. & OS10 & 21 & 609 & 0.10 & 0.704739 & 5 & 0.70426 & 1.63 & 8.4 & 0.1174 & 0.512439 & 3 & -0.5 \\
\hline Micaschist & OSB26c & 260 & 176 & 4.29 & 0.734924 & 4 & 0.71442 & 40.67 & 202 & 0.1214 & 0.512440 & 4 & -0.6 \\
\hline
\end{tabular}

Monzogr.: monzogranite; Syenogr.: syenogranite; Trondhj: trondhjemite.

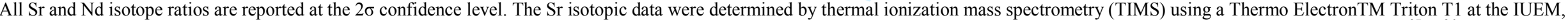

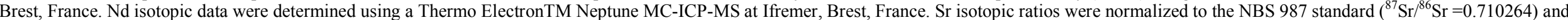

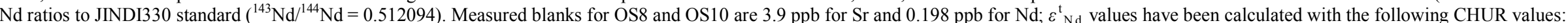

${ }^{143} \mathrm{Nd} /{ }^{144} \mathrm{Nd}=0.512638$ and ${ }^{147} \mathrm{Sm} /{ }^{144} \mathrm{Nd}=0.1967 .336 \mathrm{Ma}$ is used as approximate age of crystallization. 